\title{
TANK 7 CHARACTERIZATION AND WASHING STUDIES
}

D.P. Lambert

J.M. Pareizs

D.R. Click

February 4, 2010

Savannah River National Laboratory Savannah River Nuclear Solutions Aiken, SC 29808

Prepared for the U.S. Department of Energy under contract number DE-AC09-08SR22470.

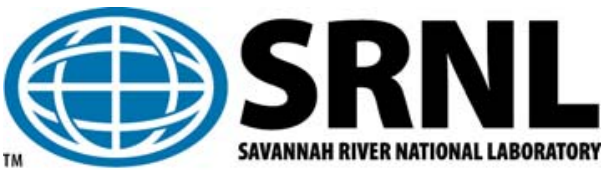


SRNL-STI-2009-00774

Revision 0

\section{DISCLAIMER}

This work was prepared under an agreement with and funded by the U.S. Government. Neither the U.S. Government or its employees, nor any of its contractors, subcontractors or their employees, makes any express or implied:

1. warranty or assumes any legal liability for the accuracy, completeness, or for the use or results of such use of any information, product, or process disclosed; or

2. representation that such use or results of such use would not infringe privately owned rights; or

3. endorsement or recommendation of any specifically identified commercial product, process, or service.

Any views and opinions of authors expressed in this work do not necessarily state or reflect those of the United States Government, or its contractors, or subcontractors.

\section{Printed in the United States of America \\ Prepared for \\ U.S. Department of Energy}




\section{REVIEWS AND APPROVALS}

AUTHORS:

D.P. Lambert, Process Technology Programs

Date

J.M. Pareizs, Process Technology Programs

Date

D.R. Click, Analytical Development

Date

TECHNICAL REVIEW:

S.H. Reboul, Process Technology Programs

Date

APPROVAL:

C.C. Herman, Manager

Date

Process Technology Programs

S.L. Marra, Manager

Date

Environmental \& Chemical Process Technology Research Programs

J.E. Occhipinti, Manager

Date

Waste Solidification Engineering 
SRNL-STI-2009-00774

Revision 0

\section{EXECUTIVE SUMMARY}

A 3-L PUREX sludge sample from Tank 7 was characterized and then processed through a series of inhibited water washes to remove oxalate, sodium, and other soluble ions. Current plans use Tank 7 as one of the feed sources for Sludge Batch 7 (SB7). Tank 7 is high in oxalate due to the oxalic acid cleaning of the sludge heels from Tanks 5 and 6 and subsequent transfer to Tank 7.

Ten decant and nine wash cycles were performed over a 47 day period at ambient temperature. Initially, seven decants and seven washes were completed based on preliminary estimates of the number of wash cycles required to remove the oxalate in the sludge. After reviewing the composition data, SRNL recommended the completion of 2 or 3 more decant/wash cycles to ensure all of the sodium oxalate had redissolved. In the first 7 washes, the slurry oxalate concentration was $12,300 \mathrm{mg} / \mathrm{kg}(69.6 \%$ oxalate removal compared to $96.1 \%$ removal of the other soluble ions). After all ten decants were complete, the slurry oxalate concentration was $3,080 \mathrm{mg} / \mathrm{kg}(89.2 \%$ oxalate removal compared to $99.0 \%$ of the other soluble ions). The rate of dissolution of oxalate increased significantly with subsequent washes until all of the sodium oxalate had been redissolved after seven decant/wash cycles. The measured oxalate concentrations agreed very well with LWO predictions for washing of the Tank 7 sample.

Highlights of the analysis and washing of the Tank 7 sample include:

- Sodium oxalate was detected in the as-received filtered solids. $95 \%$ of the oxalate was insoluble (undissolved) in the as-received slurry.

- No sodium oxalate was detected in the post-wash filtered solids.

- Sodium oxalate is the last soluble species that redissolves during washing with inhibited water. In order to significantly reduce the sodium oxalate concentration, the sludge must be highly washed, leaving the other soluble anions and cations (including sodium) very low in concentration.

- The post-wash slurry had $1 \%$ of the soluble anions and cations remaining, with the exception of sodium and oxalate, for which the percentages were $2.8 \%$ and $10.8 \%$ respectively. The post-wash sodium concentration was $9.25 \mathrm{wt} \%$ slurry total solids basis and $0.15 \mathrm{M}$ supernate.

- The settling rate of slurry was very fast allowing the completion of one decant/wash cycle each day.

- The measured yield stress of as-received (6.42 $\mathrm{wt} \%$ undissolved solids) and post-wash ( $7.77 \mathrm{wt} \%$ undissolved solids) slurry was $<1 \mathrm{~Pa}$. For rapidly settling slurries, it can be hard to measure the yield stress of the slurry so this result may be closer to the supernate result than the slurry.

The recommended strategy for developing the oxalate target for sludge preparation for Sludge Batch 7 includes the following steps:

1. CPC simulant testing to determine the percent oxalate destruction and acid mix needed to produce a predicted redox of approximately $0.2 \mathrm{Fe}^{+2} / \Sigma \mathrm{Fe}$ in a SME product while meeting all DWPF processing constraints.

2. Perform a DWPF melter flammability assessment to ensure that the additional carbon in the oxalate together with other carbon sources will not lead to a flammability issue.

3. Perform a DWPF glass paper assessment to ensure the glass produced will meet all DWPF glass limits due to the sodium concentration in the sludge batch. 
SRNL-STI-2009-00774

Revision 0

The testing would need to be repeated if a significant CPC processing change, such as an alternative reductant to formic acid, is implemented. 


\section{TABLE OF CONTENTS}

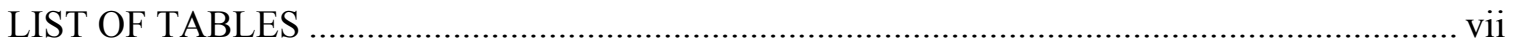

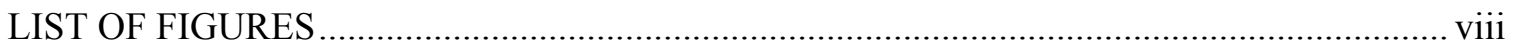

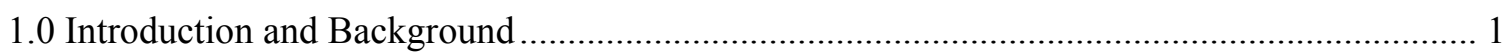

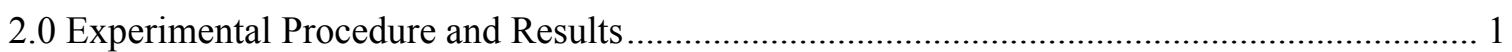

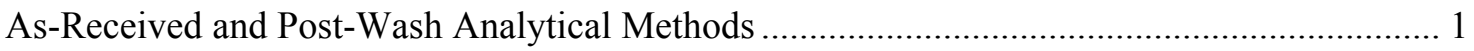

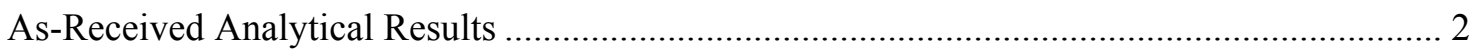

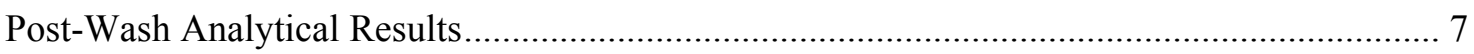

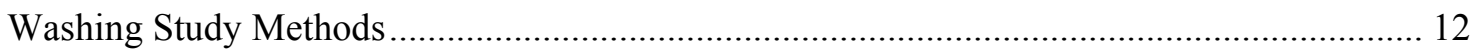

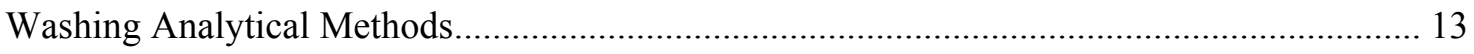

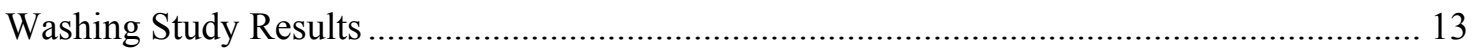

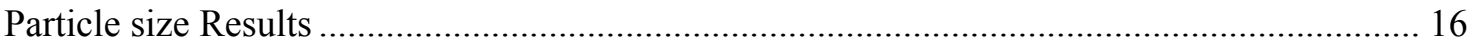

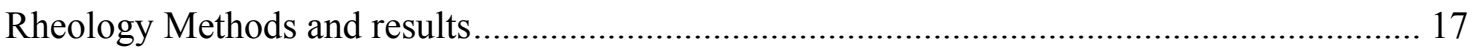

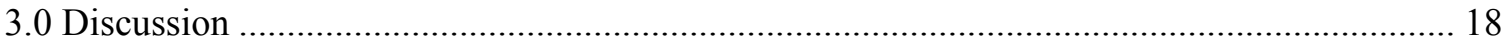

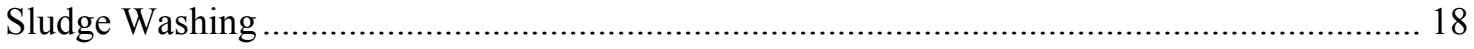

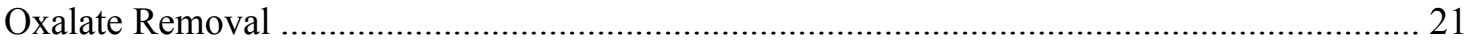

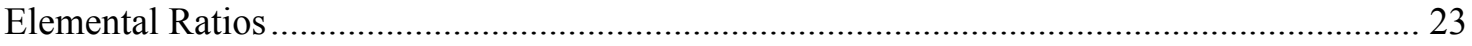

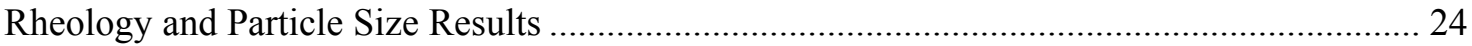

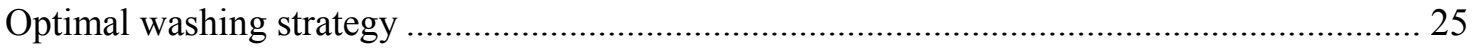

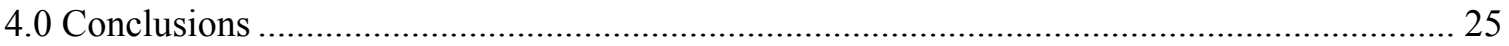

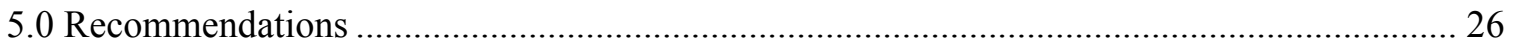

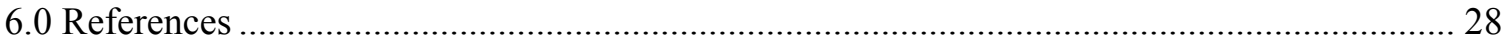

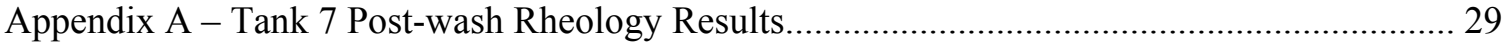




\section{LIST OF TABLES}

Table 2-1. - As-Received Tank 7 Slurry Oxalate Concentration, $\mathrm{mg} / \mathrm{kg}$..................................... 2

Table 2-2 - As-Received Tank 7 Solids and Density .................................................................. 3

Table 2-3 - As-Received Tank 7 Slurry Titration Results ............................................................ 3

Table 2-4 - As-Received Tank 7 Slurry Carbon Results, $\mathrm{mg} / \mathrm{kg}$................................................ 3

Table 2-5 - As-Received Tank 7 Slurry Mercury Concentration, wt \% total solids basis.............. 3

Table 2-6 - As-Received Tank 7 Slurry ICP-AES Concentration, wt \% total dried solids basis .... 4

Table 2-7 - As-Received Tank 7 Supernate Anion Concentration ............................................... 5

Table 2-8 - As-Received Tank 7 Supernate* ICP-AES Concentration, mg/L .............................. 6

Table 2-9 As-Received Tank 7 Supernate Gamma Spec, dpm/mL ............................................ 6

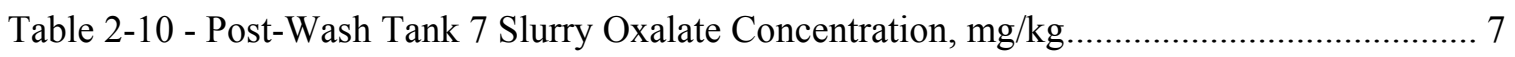

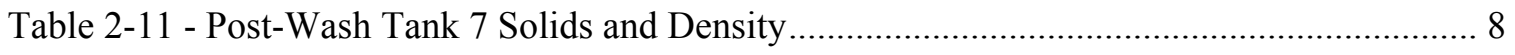

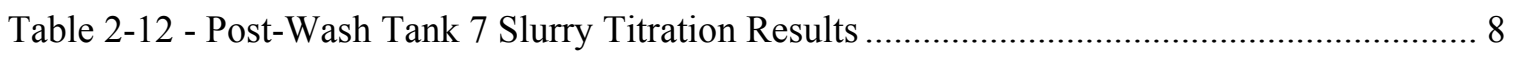

Table 2-13 - Post-Wash Tank 7 Slurry Mercury Concentration, wt \% total solids basis ................ 8

Table 2-14 - Post-Wash Tank 7 Slurry ICP-AES Concentration, wt \% total solids basis............... 9

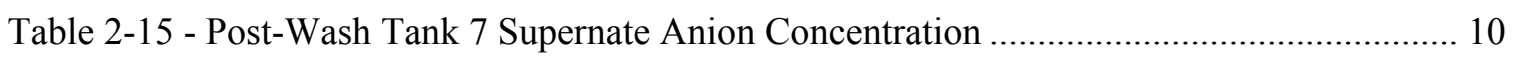

Table 2-16 Post-Wash Tank 7 Supernate* ICP-AES Concentration, mg/L ................................ 11

Table 2-17 - Tank 7 Supernate Anion Concentration during Washing, $\mathrm{mg} / \mathrm{kg}$............................ 14

Table 2-18 -- Tank 7 Supernate ICP-AES during Washing, mg/L........................................... 15

Table 2-19 - Tank 7 pH, Solids and Density during Washing ................................................... 16

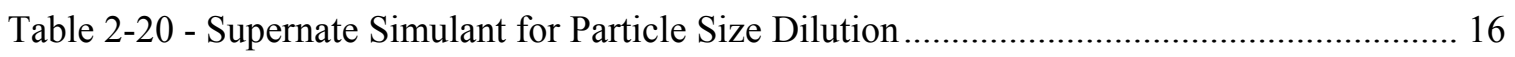

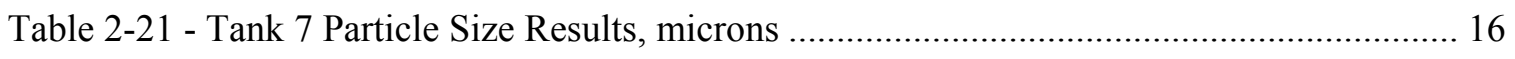

Table 2-22 - Rheology Specifications and Flow Curve Program................................................ 18

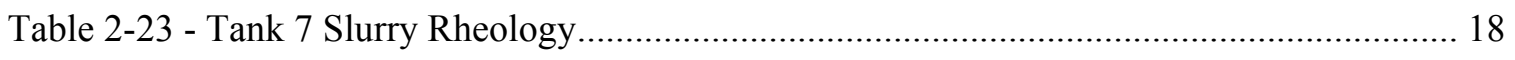

Table 3-1 Calculated Volume and Volume Ratio Data during Washing ................................... 19

Table 3-2 Calculated Concentration Ratios Data during Washing............................................. 19

Table 3-3 - Determination of Overall Wash Ratio for Slurry.................................................... 21

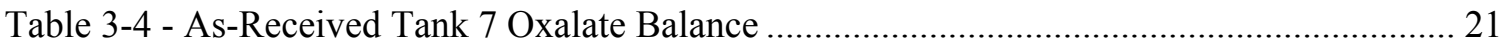


Table 3-5 - Post-Wash Tank 7 Oxalate Balance. 22

Table 3-6 - Cumulative Percent Removal of Soluble Ions and Oxalate during Slurry Washing .. 23

Table 3-7 - Iron to Elemental Ratios and Predicted Post-Wash Composition

\section{LIST OF FIGURES}

Figure 1-1- As-Received Tank 7 Washed $^{\&}$ Sludge Solids XRD Analysis................................... 7

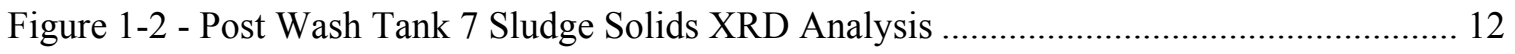

Figure 2-1 - Volume and Concentration Wash Ratios (R) throughout Washing ......................... 20

Figure 2-2 - Sodium, $\mathrm{M}$ and Oxalate, $\mathrm{mg} / \mathrm{L}$ Profile throughout Washing .................................. 22 


\section{LIST OF ABBREVIATIONS}

\begin{tabular}{|c|c|}
\hline $\mathrm{AD}$ & Analytical Development \\
\hline $\mathrm{ARG}-1$ & Analytical Reference Glass - 1 \\
\hline CV-AA & Cold Vapor - Atomic Absorption Spectroscopy \\
\hline DWPF & Defense Waste Processing Facility \\
\hline IC & Ion Chromatography \\
\hline DI & Deionized \\
\hline ICP-AES & Inductively Coupled Plasma - Atomic Emission Spectroscopy \\
\hline $\mathrm{HM}$ & H-Area Modified PUREX \\
\hline $\mathrm{L}$ & Liter \\
\hline M & Molar \\
\hline NA & Not Available (Not Measured) \\
\hline NIST & National Institute of Standards and Testing \\
\hline PUREX & Plutonium Uranium Redox Extraction \\
\hline RSD & Relative Standard Deviation \\
\hline SB6 & Sludge Batch 6 \\
\hline SB7 & Sludge Batch 7 \\
\hline SRNL & Savannah River National Laboratory \\
\hline St Dev. & Standard Deviation \\
\hline TTQAP & Task Technical and Quality Assurance Plan \\
\hline $\mathrm{TIC}$ & Total Inorganic Carbon \\
\hline TOC & Total Organic Carbon \\
\hline TTR & Task Technical Request \\
\hline WSE & Waste Solidification Engineering \\
\hline $\mathrm{Wt} \%$ & Weight Percent \\
\hline XRD & X-ray Diffraction \\
\hline
\end{tabular}




\subsection{Introduction and Background}

A sample of Plutonium Uranium Redox Extraction (PUREX) sludge from Tank 7 was characterized and a washing study was performed to support Sludge Batch 7 (SB7) planning and preparation. The slurry in Tank 7 has a high oxalate concentration since it came from oxalic acid cleaning of Tanks 5 and 6. It was expected that the Tank 7 sample would contain both sodium oxalate and iron oxalate.

Savannah River National Laboratory (SRNL) analyses of Tank 7 were requested by Waste Solidification Engineering (WSE) via Technical Task Request (TTR) HLE-TTR$2009-00027^{1}$. The sample preparation and analysis work is governed by a Task Technical and Quality Assurance Plan (TTQAP) ${ }^{2}$, and modifications received via customer communications ${ }^{3,4}$. Additional scope included a request for analysis of Cs$137 / \mathrm{Ba}-137 \mathrm{~m}$ in the as-received slurry sample, completion of two additional wash cycles, and analysis of the post-wash solids using X-ray Diffraction (XRD).

One 3-L sample of Tank 7 was pulled on June 29, 2009 by F-Tank Farm Operations following slurry operations. The sample \# is FTF-07-09-37. The sample was received in the SRNL Shielded Cells on June 30, 2009.

SB7 is not the first sludge batch that is high in oxalate. SB3 was primarily Tank 7 sludge and was also relatively high in oxalate ${ }^{5}$. Simulant testing completed in qualifying the sludge processing for SB3 was completed at oxalate concentrations as high as 40,000 $\mathrm{mg} / \mathrm{kg}^{6}$. Although the simulant testing was completed at elevated oxalate concentrations, the measured oxalate concentration in Tank 51, after the Tank 7 transfer for SB3, was $1,590 \mathrm{mg} / \mathrm{kg}$ and the actual SB3 blend in Tank 40 was $919 \mathrm{mg} / \mathrm{kg}$ oxalate $^{7}$.

\subsection{Experimental Procedure and Results}

The methods for preparing and analyzing the samples, together with the analytical results are summarized in this section. For instances where results were both above and below the analytical detection limit, the mean value was calculated using all four results, assuming any analysis below the detection limit was at the detection limit to be conservatively high. No estimate is made of the uncertainty in these cases.

As-Received and Post-Wash Analytical Methods

At the SRNL Shielded Cells facility, the 3-L Tank 7 sample was transferred from the shipping container into a calibrated 4-L glass bottle. The insoluble solids were allowed to settle overnight. Supernate was then siphoned off and circulated through the shipping container to complete the transfer of the sample of 3,673 g. Following thorough mixing of the 3-L sample, three subsamples, totaling $433 \mathrm{~g}$, were removed. These sub-samples were then utilized for all subsequent as-received analytical samples. Once all of the washing was complete, 1,482 $\mathrm{g}$ of slurry remained. Following thorough mixing of the 3-L post-wash slurry, two sub-samples, totaling $153 \mathrm{~g}$, were removed. In addition, $559 \mathrm{~g}$ of supernate was available for any required supernate analyses. These sub-samples were then utilized for all subsequent post-wash analytical samples. 
Eight separate aliquots of the slurry were digested, four with $\mathrm{HNO}_{3} / \mathrm{HCl}$ (aqua regia ${ }^{8}$ ) in sealed Teflon ${ }^{\circledR}$ vessels and four in $\mathrm{Na}_{2} \mathrm{O}_{2}$ (alkali or peroxide fusion ${ }^{9}$ ) using $\mathrm{Zr}$ crucibles. Due to the use of $\mathrm{Zr}$ crucibles and $\mathrm{Na}$ in the peroxide fusions, $\mathrm{Na}$ and $\mathrm{Zr}$ cannot be determined from this preparation. Additionally, other alkali metals, such as Li and $\mathrm{K}$ that may be contaminants in the $\mathrm{Na}_{2} \mathrm{O}_{2}$ are not determined from this preparation. Three Analytical Reference Glass - 1 (ARG-1) standards ${ }^{10}$ were digested along with a blank for each preparation. The ARG-1 glass allows for an assessment of the completeness of each digestion. Each aqua regia digestion and blank was diluted 1:100 by volume with deionized (DI) water and submitted to Analytical Development (AD) for inductively coupled plasma - atomic emission spectroscopy (ICP-AES) analysis and cold vapor atomic absorption (CV-AA) analysis for $\mathrm{Hg}$. Equivalent dilutions of the peroxide fusion digestions and blank were submitted to AD for ICP-AES analysis.

Four separate aliquots of the slurry were diluted 20:1 by mass with DI water and submitted to AD for Total Inorganic Carbon (TIC)/Total Organic Carbon (TOC) analysis. Four separate aliquots of the slurry were diluted 20:1 by mass with DI water and submitted to AD for analysis by titration to determine the free hydroxide and total base concentration.

Four separate aliquots of the slurry were digested with equal volumes of nitric and hydrochloric acid, a special preparation approach to ensure complete digestion of all oxalate. The samples were quickly transferred out of the cells and analyzed by Ion Chromatography (IC) for oxalate within 24 hours to minimize decomposition of the oxalate. As large quantities of nitrate and chloride were added with this preparation, only oxalate was reported from this analysis.

Tank 7 supernate was collected with a $0.45 \mu \mathrm{m}$ filter cup from a mixed slurry sample in the SRNL Shielded Cells and submitted to AD for ICP-AES and IC. The IC and ICP-AES samples were diluted 50:1 by volume with DI water. The solids remaining on the filter were washed well with DI water, dried, and submitted to AD for XRD analysis.

Four separate aliquots of the slurry before and after washing were analyzed in the Shielded Cells for density. Four separate aliquots of the slurry were analyzed in the Shielded Cells for total slurry solids.

Four separate aliquots of the filtered supernate before and after washing were analyzed in the Shielded Cells for density. Four filtered separate aliquots of the supernate were analyzed in the Shielded Cells for total supernate solids.

\section{$\underline{\text { As-Received Analytical Results }}$}

The as-received results were reported in a memo ${ }^{11}$ on September 16, 2009 and the memo was reissued $^{12}$ on October 13, 2009 with added XRD and supernate ICP-AES data. These data are reported again in the following tables. The only change from the original memo is that the oxalate balance has been moved to Section 2.2. These data are reported in Tables 1-1 to 1-9 and Figure 11.

Table 2-1. - As-Received Tank 7 Slurry Oxalate Concentration, mg/kg

\begin{tabular}{|l|c|c|c|}
\hline Anion & Result & Std. Dev. & \%RSD \\
\hline Oxalate & 18,100 & 218 & 1.20 \\
\hline
\end{tabular}


Table 2-2 - As-Received Tank 7 Solids and Density

\begin{tabular}{|l|c|c|c|}
\hline Analysis & Result & Std. Dev. & \%RSD \\
\hline Wt \% Total Solids & 24.3 & 0.205 & 0.845 \\
\hline Wt \% Dissolved Solids (uncorrected) & 19.1 & 0.183 & 0.956 \\
\hline Wt \% Insoluble Solids (Corrected) & 6.32 & 0.425 & 6.72 \\
\hline Wt \% Soluble Solids & 17.9 & 0.608 & 3.39 \\
\hline Slurry Density, g/mL & 1.24 & 0.011 & 0.888 \\
\hline Supernate Density, g/mL & 1.17 & 0.009 & 0.767 \\
\hline
\end{tabular}

Table 2-3 - As-Received Tank 7 Slurry Titration Results

\begin{tabular}{|r|c|c|c|}
\hline & Free OH, $\mathbf{M}$ & Total Base, $\mathbf{M}$ & Other Base Excluding Carbonate, $\mathbf{M}$ \\
\hline Average & 1.68 & 2.25 & 0.296 \\
\hline Std. Dev. & 0.133 & 0.055 & 0.012 \\
\hline \%RSD & 7.92 & 2.43 & 4.03 \\
\hline
\end{tabular}

Table 2-4 - As-Received Tank 7 Slurry Carbon Results, mg/kg

\begin{tabular}{|c|c|c|c|c|c|}
\hline Analysis & $\begin{array}{c}\text { Total } \\
\text { Carbon }\end{array}$ & $\begin{array}{c}\text { Total Inorganic } \\
\text { Carbon }\end{array}$ & $\begin{array}{c}\text { Total Organic } \\
\text { Carbon }\end{array}$ & $\begin{array}{c}\text { TOC if } \\
\text { Oxalate* }\end{array}$ & $\begin{array}{c}\text { TIC if } \\
\text { Carbonate, } \mathbf{M}^{\boldsymbol{*}}\end{array}$ \\
\hline Average & 6,950 & 1,370 & 5,580 & 20,400 & 0.141 \\
\hline Std. Dev. & 245 & 46.3 & 225 & 824 & 0.0048 \\
\hline \%RSD & 3.53 & 3.38 & 4.03 & 4.03 & 3.38 \\
\hline
\end{tabular}

* If all the organic carbon is present as oxalate, the oxalate concentration would be $5580 \mathrm{mg} \mathrm{C} / \mathrm{kg}$ * $\mathrm{mol} \mathrm{C} / 12.0107 \mathrm{~g} *$ mol oxalate $/ 2 \mathrm{~mol} \mathrm{C} * 88.019 \mathrm{~g}$ oxalate $/ \mathrm{mol}$

\& If all the inorganic carbon is present as carbonate, the carbonate concentration would be $1370 \mathrm{mg}$ $\mathrm{C} / \mathrm{kg} * 1.239 \mathrm{~kg} / \mathrm{L} * \mathrm{~g} / 1000 \mathrm{mg} * \mathrm{~mol} \mathrm{C} / 12.0107 \mathrm{~g}$

Table 2-5 - As-Received Tank 7 Slurry Mercury Concentration, wt \% total solids basis

\begin{tabular}{|l|c|c|c|}
\hline Metal & Concentration & Std. Dev. & \%RSD \\
\hline Mercury & 0.0492 & 0.0018 & 3.62 \\
\hline
\end{tabular}


Table 2-6 - As-Received Tank 7 Slurry ICP-AES Concentration, wt \% total dried solids basis

\begin{tabular}{|c|c|c|c|c|}
\hline Element & Prep & Wt\% & Std. Dev. & \%RSD \\
\hline $\mathrm{Ag}$ & AR & $<9.70 \mathrm{E}-03$ & $\mathrm{NA}$ & $\mathrm{NA}$ \\
\hline $\mathrm{Al}$ & $\mathrm{PF}$ & $2.58 \mathrm{E}+00$ & $1.41 \mathrm{E}-02$ & $5.5 \mathrm{E}-01$ \\
\hline $\mathrm{B}$ & AR & $2.09 \mathrm{E}-02$ & $7.93 \mathrm{E}-04$ & $3.8 \mathrm{E}+00$ \\
\hline $\mathrm{Ba}$ & $\mathrm{AR} / \mathrm{PF}$ & $2.79 \mathrm{E}-02$ & $4.71 \mathrm{E}-04$ & $1.7 \mathrm{E}+00$ \\
\hline $\mathrm{Be}$ & $\mathrm{PF}$ & $<2.56 \mathrm{E}-03$ & $\mathrm{NA}$ & $\mathrm{NA}$ \\
\hline $\mathrm{Ca}$ & AR & $2.04 \mathrm{E}-01$ & $5.35 \mathrm{E}-03$ & $2.62 \mathrm{E}+00$ \\
\hline $\mathrm{Cd}$ & $\mathrm{AR} / \mathrm{PF}$ & $1.76 \mathrm{E}-02$ & $4.17 \mathrm{E}-04$ & $2.37 \mathrm{E}+00$ \\
\hline $\mathrm{Ce}$ & AR & $3.47 \mathrm{E}-02$ & $1.28 \mathrm{E}-03$ & $3.68 \mathrm{E}+00$ \\
\hline $\mathrm{Cr}$ & $\mathrm{AR} / \mathrm{PF}$ & $3.87 \mathrm{E}-02$ & $4.58 \mathrm{E}-03$ & $1.18 \mathrm{E}+01$ \\
\hline $\mathrm{Cu}$ & $\mathrm{AR} / \mathrm{PF}$ & $1.21 \mathrm{E}-02$ & $7.98 \mathrm{E}-04$ & $6.62 \mathrm{E}+00$ \\
\hline $\mathrm{Fe}$ & $\mathrm{AR} / \mathrm{PF}$ & $4.38 \mathrm{E}+00$ & $4.31 \mathrm{E}-01$ & $9.84 \mathrm{E}+00$ \\
\hline $\mathrm{Gd}$ & $\mathrm{AR}$ & $<8.81 \mathrm{E}-03$ & NA & $\mathrm{NA}$ \\
\hline $\mathrm{K}$ & AR & $4.59 \mathrm{E}-01$ & $2.52 \mathrm{E}-02$ & $5.48 \mathrm{E}+00$ \\
\hline $\mathrm{La}$ & AR & $1.41 \mathrm{E}-02$ & $3.56 \mathrm{E}-04$ & $2.52 \mathrm{E}+00$ \\
\hline $\mathrm{Li}$ & AR & $1.48 \mathrm{E}-02$ & $4.69 \mathrm{E}-04$ & $3.17 \mathrm{E}+00$ \\
\hline $\mathrm{Mg}$ & $\mathrm{AR} / \mathrm{PF}$ & $1.15 \mathrm{E}-01$ & $9.16 \mathrm{E}-03$ & $7.94 \mathrm{E}+00$ \\
\hline $\mathrm{Mn}$ & $\mathrm{AR} / \mathrm{PF}$ & $9.23 \mathrm{E}-01$ & $1.43 \mathrm{E}-02$ & $1.55 \mathrm{E}+00$ \\
\hline Mo & AR & $9.60 \mathrm{E}-03$ & $3.30 \mathrm{E}-04$ & $3.44 \mathrm{E}+00$ \\
\hline $\mathrm{Na}$ & AR & $3.18 \mathrm{E}+01$ & $1.00 \mathrm{E}+00$ & $3.15 \mathrm{E}+00$ \\
\hline $\mathrm{Ni}$ & $\mathrm{AR} / \mathrm{PF}$ & $7.18 \mathrm{E}-01$ & $1.47 \mathrm{E}-02$ & $2.04 \mathrm{E}+00$ \\
\hline $\mathrm{P}$ & AR & 7.46E-02 & $2.40 \mathrm{E}-03$ & $3.22 \mathrm{E}+00$ \\
\hline $\mathrm{Pb}$ & AR & $9.43 \mathrm{E}-03$ & $5.77 \mathrm{E}-04$ & $6.12 \mathrm{E}+00$ \\
\hline $\mathrm{S}$ & AR & $3.36 \mathrm{E}-01$ & $2.72 \mathrm{E}-02$ & $8.12 \mathrm{E}+00$ \\
\hline $\mathrm{Sb}$ & AR & $<1.03 \mathrm{E}-02$ & NA & NA \\
\hline $\mathrm{Si}$ & $\mathrm{PF}$ & $5.89 \mathrm{E}-01$ & $1.22 \mathrm{E}-02$ & $2.07 \mathrm{E}+00$ \\
\hline $\mathrm{Sn}$ & AR & $<5.19 \mathrm{E}-03$ & NA & NA \\
\hline $\mathrm{Sr}$ & $\mathrm{AR} / \mathrm{PF}$ & $1.35 \mathrm{E}-02$ & $8.43 \mathrm{E}-04$ & $6.24 \mathrm{E}+00$ \\
\hline $\mathrm{Ti}$ & $\mathrm{AR} / \mathrm{PF}$ & $7.35 \mathrm{E}-03$ & $5.84 \mathrm{E}-04$ & $7.94 \mathrm{E}+00$ \\
\hline $\mathrm{U}$ & $\mathrm{AR} / \mathrm{PF}$ & $2.04 \mathrm{E}+00$ & $1.27 \mathrm{E}-01$ & $6.22 \mathrm{E}+00$ \\
\hline V & $\mathrm{AR}$ & $<4.81 \mathrm{E}-03$ & NA & NA \\
\hline $\mathrm{Zn}$ & $\mathrm{AR} / \mathrm{PF}$ & $1.65 \mathrm{E}-02$ & $2.04 \mathrm{E}-03$ & $1.24 \mathrm{E}+01$ \\
\hline $\mathrm{Zr}$ & AR & $6.54 \mathrm{E}-02$ & $1.40 \mathrm{E}-03$ & $2.14 \mathrm{E}+00$ \\
\hline
\end{tabular}

Note:

$\mathrm{AR}=$ Aqua Regia Digestion

$\mathrm{PF}=$ Peroxide Fusion Digestion 
Table 2-7 - As-Received Tank 7 Supernate Anion Concentration

\begin{tabular}{|c|c|c|c|c|}
\hline Anion & $\begin{array}{c}\text { Result, } \\
\text { mg/kg }\end{array}$ & Std. Dev. & \%RSD & $\begin{array}{c}\text { Result, } \\
\text { Molarity }\end{array}$ \\
\hline Fluoride & $<244$ & NA & NA & $<0.0150$ \\
\hline Formate & $<244$ & NA & NA & $<0.0064$ \\
\hline Chloride & 244 & 5.94 & 2.44 & 0.0081 \\
\hline Nitrite & 19,500 & 60.5 & 0.31 & 0.497 \\
\hline Bromide & $<1220$ & NA & NA & $<0.0179$ \\
\hline Nitrate & 36,600 & 184 & 0.50 & 0.692 \\
\hline Phosphate & 292 & 7.13 & 2.44 & 0.0036 \\
\hline Sulfate & 2,000 & 10.7 & 0.53 & 0.0244 \\
\hline Oxalate & 1,000 & 5.33 & 0.53 & 0.0133 \\
\hline
\end{tabular}


Table 2-8 - As-Received Tank 7 Supernate* ICP-AES Concentration, mg/L

\begin{tabular}{|c|c|c|c|}
\hline Element & Result & Std. Dev. & $\%$ RSD \\
\hline $\mathrm{Ag}$ & $<1.60$ & NA & NA \\
\hline $\mathrm{Al}$ & 5,320 & 72.5 & 1.36 \\
\hline B & 56.4 & 0.243 & 0.431 \\
\hline $\mathrm{Ba}$ & $<3.86$ & NA & NA \\
\hline $\mathrm{Be}$ & $<0.949$ & NA & NA \\
\hline $\mathrm{Ca}$ & 5.39 & 0.429 & 7.96 \\
\hline $\mathrm{Cd}^{\#}$ & 0.886 & 0.150 & 16.9 \\
\hline $\mathrm{Ce}$ & $<5.58$ & NA & NA \\
\hline $\mathrm{Cr}$ & 69.3 & 0.193 & 0.278 \\
\hline $\mathrm{Cu}$ & $<1.29$ & NA & NA \\
\hline $\mathrm{Fe}$ & $<2.79$ & NA & $\mathrm{NA}$ \\
\hline $\mathrm{Gd}$ & $<2.64$ & NA & NA \\
\hline $\mathrm{K}$ & 1,060 & 9.00 & 0.849 \\
\hline $\mathrm{La}$ & $<2.30$ & NA & NA \\
\hline $\mathrm{Li}$ & $<4.69$ & NA & NA \\
\hline $\mathrm{Mg}$ & $<1.15$ & NA & NA \\
\hline $\mathrm{Mn}$ & $<1.23$ & NA & NA \\
\hline Mo & 23.0 & 0.306 & 1.33 \\
\hline $\mathrm{Na}$ & 88,000 & 460 & 0.523 \\
\hline $\mathrm{Ni}$ & $<5.23$ & NA & NA \\
\hline $\mathrm{P}$ & 137 & 0.553 & 0.404 \\
\hline $\mathrm{Pb}$ & $<7.89$ & NA & NA \\
\hline $\mathrm{S}$ & 903 & 32.3 & 3.58 \\
\hline $\mathrm{Sb}$ & $<14.7$ & NA & NA \\
\hline $\mathrm{Si}$ & $<13.6$ & NA & NA \\
\hline $\mathrm{Sn}$ & $<3.73$ & NA & NA \\
\hline $\mathrm{Sr}$ & $<0.617$ & NA & NA \\
\hline $\mathrm{Ti}$ & $<2.37$ & NA & NA \\
\hline $\mathrm{U}$ & $<33.4$ & NA & NA \\
\hline $\mathrm{V}$ & $<2.77$ & NA & NA \\
\hline $\mathrm{Zn}$ & 2.27 & 0.308 & 13.6 \\
\hline $\mathrm{Zr}$ & $<1.29$ & NA & NA \\
\hline
\end{tabular}

* The supernate was diluted $\sim 50: 1$ with water

\# The Cd concentration was calculated using the two analyses above the detection limit.

Table 2-9 As-Received Tank 7 Supernate Gamma Spec, dpm/mL

\begin{tabular}{|l|l|l|}
\hline Analysis & Cs-134 & Cs-137 \\
\hline Mean value, dpm/mL & $5.70 \mathrm{E}+04$ & $6.01 \mathrm{E}+08$ \\
\hline Std. Dev. & $5.16 \mathrm{E}+03$ & $1.17 \mathrm{E}+07$ \\
\hline \%RSD & $9.05 \mathrm{E}+00$ & $1.94 \mathrm{E}+00$ \\
\hline
\end{tabular}


SRNL-STI-2009-00774

Revision 0

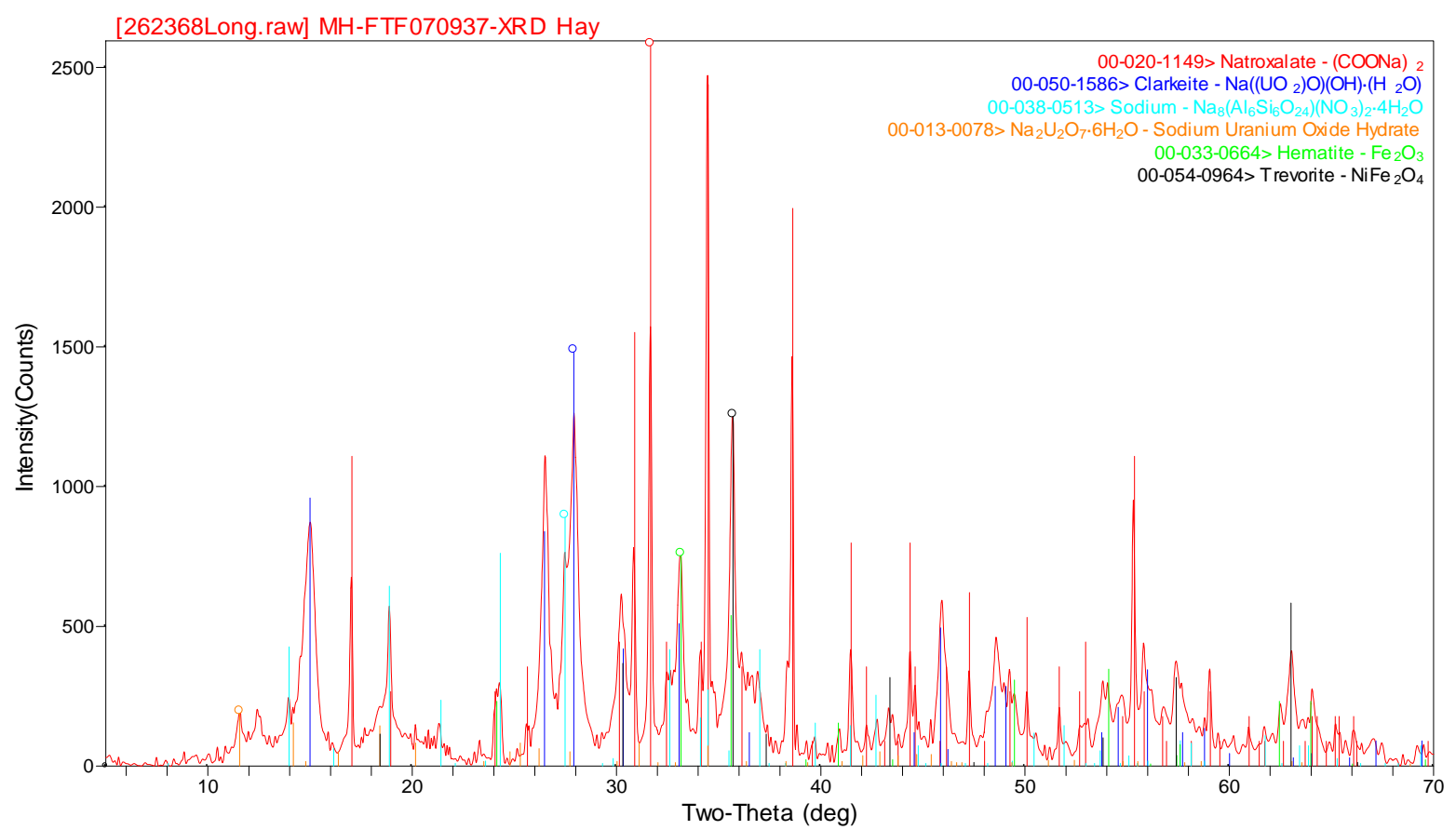

Figure 2-1- As-Received Tank 7 Washed $^{\&}$ Sludge Solids XRD Analysis

\& The Tank 7 slurry was filtered and the solids were washed with water to remove as much soluble radioactive isotopes as feasible (mainly Cs-137). The remaining solids were analyzed using XRD. Natroxalate $(\mathrm{COONa})_{2}$ is also referred to as sodium oxalate.

Post-Wash Analytical Results

After the ninth wash and tenth decant were completed, a supernate sample was submitted for analysis by $\mathrm{AD}$. The data is reported in Tables 1-10 to 1-16 and Figure 1-2.

Table 2-10 - Post-Wash Tank 7 Slurry Oxalate Concentration, mg/kg

\begin{tabular}{|l|c|c|c|}
\hline Anion & Result & Std. Dev. & \%RSD \\
\hline Oxalate & 1,310 & 156 & 11.9 \\
\hline
\end{tabular}


Table 2-11 - Post-Wash Tank 7 Solids and Density

\begin{tabular}{|l|c|c|c|}
\hline Analysis & Result & Std. Dev. & \%RSD \\
\hline Wt \% Total Dried Solids & 8.73 & 0.02 & 0.259 \\
\hline Wt \% Dissolved Solids (uncorrected) & 1.04 & 0.04 & 3.83 \\
\hline Wt \% Insoluble Solids (Corrected) & 7.77 & 0.08 & 0.997 \\
\hline Wt \% Soluble Solids & 0.932 & 0.10 & 10.7 \\
\hline Slurry Density, g/mL* & 1.07 & 0.00 & 0.396 \\
\hline Supernate Density, g/mL & 1.01 & 0.00 & 0.423 \\
\hline
\end{tabular}

* Average of 3 valid supernate density measurements, the fourth measurement had a density $<1$, likely due to inadequate filling of density tube.

Table 2-12 - Post-Wash Tank 7 Slurry Titration Results

\begin{tabular}{|r|c|c|c|}
\hline & Free OH, $\mathbf{M}$ & Total Base, $\mathbf{M}$ & Other Base Excluding Carbonate, $\mathbf{M}$ \\
\hline Average & 0.0214 & 0.442 & 0.0214 \\
\hline StDev & 0.000 & 0.029 & 0.000 \\
\hline \%RSD & 1.93 & 6.56 & 1.93 \\
\hline
\end{tabular}

Table 2-13 - Post-Wash Tank 7 Slurry Mercury Concentration, wt \% total solids basis

\begin{tabular}{|l|c|c|c|}
\hline Metal & Concentration & Std. Dev. & \%RSD \\
\hline Mercury & 0.178 & 0.0492 & 2.77 \\
\hline
\end{tabular}


Table 2-14 - Post-Wash Tank 7 Slurry ICP-AES Concentration, wt \% total solids basis

\begin{tabular}{|c|c|c|c|c|}
\hline Element & Prep & Wt\% & Std. Dev. & $\%$ RSD \\
\hline $\mathrm{Ag}$ & $\mathrm{AR}$ & $2.68 \mathrm{E}-02$ & $1.29 \mathrm{E}-04$ & $4.83 \mathrm{E}-01$ \\
\hline $\mathrm{Al}$ & PF/AR & $4.3 \mathrm{E}+00$ & $1.80 \mathrm{E}-01$ & $4.22 \mathrm{E}+00$ \\
\hline B & AR & $<3.83 \mathrm{E}-03$ & NA & NA \\
\hline $\mathrm{Ba}$ & $\mathrm{AR} / \mathrm{PF}$ & $1.30 \mathrm{E}-01$ & $3.66 \mathrm{E}-03$ & $2.81 \mathrm{E}+00$ \\
\hline $\mathrm{Be}$ & AR & $<6.90 \mathrm{E}-05$ & NA & NA \\
\hline $\mathrm{Ca}$ & AR & $9.90 \mathrm{E}-01$ & $5.07 \mathrm{E}-03$ & $5.12 \mathrm{E}-01$ \\
\hline $\mathrm{Cd}$ & $\mathrm{AR} / \mathrm{PF}$ & $8.35 \mathrm{E}-02$ & $2.44 \mathrm{E}-03$ & $2.92 \mathrm{E}+00$ \\
\hline $\mathrm{Ce}$ & $\mathrm{AR}$ & $3.86 \mathrm{E}-01$ & $1.29 \mathrm{E}-03$ & $3.35 \mathrm{E}-01$ \\
\hline $\mathrm{Cr}$ & $\mathrm{AR} / \mathrm{PF}$ & $6.76 \mathrm{E}-02$ & $7.51 \mathrm{E}-03$ & $1.11 \mathrm{E}+01$ \\
\hline $\mathrm{Cu}$ & $\mathrm{AR} / \mathrm{PF}$ & $5.95 \mathrm{E}-02$ & $2.27 \mathrm{E}-03$ & $3.82 \mathrm{E}+00$ \\
\hline $\mathrm{Fe}$ & $\mathrm{AR} / \mathrm{PF}$ & $1.99 \mathrm{E}+01$ & $8.38 \mathrm{E}-01$ & $4.21 \mathrm{E}+00$ \\
\hline $\mathrm{Gd}$ & AR & $3.48 \mathrm{E}-02$ & $2.87 \mathrm{E}-04$ & $8.26 \mathrm{E}-01$ \\
\hline $\mathrm{K}$ & AR & $6.38 \mathrm{E}-02$ & $2.20 \mathrm{E}-03$ & $3.45 \mathrm{E}+00$ \\
\hline $\mathrm{La}$ & AR & 7.34E-02 & $5.06 \mathrm{E}-04$ & $6.89 \mathrm{E}-01$ \\
\hline $\mathrm{Li}$ & AR & $7.15 \mathrm{E}-02$ & $5.32 \mathrm{E}-04$ & 7.45E-01 \\
\hline $\mathrm{Mg}$ & $\mathrm{AR} / \mathrm{PF}$ & $6.03 \mathrm{E}-01$ & $2.34 \mathrm{E}-02$ & $3.87 \mathrm{E}+00$ \\
\hline $\mathrm{Mn}$ & $\mathrm{AR} / \mathrm{PF}$ & $4.3 \mathrm{E}+00$ & $1.63 \mathrm{E}-01$ & $3.77 \mathrm{E}+00$ \\
\hline Mo & $\mathrm{PF}$ & $<2.05 \mathrm{E}-02$ & NA & NA \\
\hline $\mathrm{Na}$ & AR & $9.25 \mathrm{E}+00$ & $1.57 \mathrm{E}-01$ & $1.70 \mathrm{E}+00$ \\
\hline $\mathrm{Ni}$ & $\mathrm{AR} / \mathrm{PF}$ & $3.31 \mathrm{E}+00$ & $1.25 \mathrm{E}-01$ & $3.77 \mathrm{E}+00$ \\
\hline $\mathrm{P}$ & $\mathrm{PF}$ & $1.27 \mathrm{E}-01$ & $3.29 \mathrm{E}-02$ & $2.60 \mathrm{E}+01$ \\
\hline $\mathrm{Pb}$ & AR & $3.90 \mathrm{E}-02$ & $6.22 \mathrm{E}-04$ & $1.59 \mathrm{E}+00$ \\
\hline $\mathrm{S}$ & $\mathrm{AR}$ & $1.16 \mathrm{E}-01$ & NA & NA \\
\hline $\mathrm{Sb}$ & $\mathrm{AR}$ & $1.70 \mathrm{E}-02$ & $3.16 \mathrm{E}-04$ & $1.86 \mathrm{E}+00$ \\
\hline $\mathrm{Si}$ & $\mathrm{PF}$ & $3.23 \mathrm{E}+00$ & $1.47 \mathrm{E}-01$ & $4.57 \mathrm{E}+00$ \\
\hline $\mathrm{Sn}$ & $\mathrm{PF}$ & $3.38 \mathrm{E}-02$ & $5.03 \mathrm{E}-03$ & $1.49 \mathrm{E}+01$ \\
\hline $\mathrm{Sr}$ & $\mathrm{AR} / \mathrm{PF}$ & $6.86 \mathrm{E}-02$ & $5.00 \mathrm{E}-03$ & $7.28 \mathrm{E}+00$ \\
\hline $\mathrm{Ti}$ & $\mathrm{AR} / \mathrm{PF}$ & $2.96 \mathrm{E}-02$ & $1.05 \mathrm{E}-03$ & $3.54 \mathrm{E}+00$ \\
\hline $\mathrm{U}$ & $\mathrm{AR} / \mathrm{PF}$ & $1.04 \mathrm{E}+01$ & $5.83 \mathrm{E}-01$ & $5.60 \mathrm{E}+00$ \\
\hline V & AR & $<5.04 \mathrm{E}-04$ & NA & NA \\
\hline $\mathrm{Zn}$ & $\mathrm{AR} / \mathrm{PF}$ & $8.16 \mathrm{E}-02$ & $3.00 \mathrm{E}-03$ & $3.68 \mathrm{E}+00$ \\
\hline $\mathrm{Zr}$ & AR & $1.12 \mathrm{E}-01$ & $6.58 \mathrm{E}-03$ & $5.88 \mathrm{E}+00$ \\
\hline
\end{tabular}

Note:

$\mathrm{AR}=$ Aqua Regia Digestion $\mathrm{PF}=$ Peroxide Fusion Digestion 
Table 2-15 - Post-Wash Tank 7 Supernate Anion Concentration

\begin{tabular}{|c|c|c|c|c|}
\hline Anion & Result, mg/kg & Std. Dev. & \%RSD & Result, Molarity \\
\hline Fluoride & $<5$ & NA & NA & $<0.0003$ \\
\hline Formate & $<5$ & NA & NA & $<0.0001$ \\
\hline Chloride & $<5$ & NA & NA & $<0.0001$ \\
\hline Nitrite & 359 & 3.24 & 0.90 & 0.0077 \\
\hline Bromide & $<5$ & NA & NA & $<0.0001$ \\
\hline Nitrate & 600 & 8.73 & 1.45 & 0.0096 \\
\hline Phosphate & $<50$ & NA & NA & $<0.0005$ \\
\hline Sulfate & $<50$ & NA & NA & $<0.0005$ \\
\hline Oxalate & 3,340 & 10.0 & 0.30 & 0.0375 \\
\hline
\end{tabular}


Table 2-16 Post-Wash Tank 7 Supernate* ICP-AES Concentration, mg/L

\begin{tabular}{|c|c|c|c|}
\hline Element & $\begin{array}{c}\text { Result, } \\
\text { mg/L }\end{array}$ & Std. Dev. & $\%$ RSD \\
\hline $\mathrm{Ag}$ & $<0.0559$ & NA & $\mathrm{NA}$ \\
\hline $\mathrm{Al}$ & 110 & 1 & 0.74 \\
\hline $\mathrm{B}$ & 1.03 & 0.01 & 0.93 \\
\hline $\mathrm{Ba}$ & 0.046 & NA & NA \\
\hline $\mathrm{Be}$ & $<0.0331$ & NA & $\mathrm{NA}$ \\
\hline $\mathrm{Ca}$ & 0.179 & 0.009 & 4.8 \\
\hline $\mathrm{Cd}$ & $<0.0244$ & NA & NA \\
\hline $\mathrm{Ce}$ & $<0.195$ & NA & NA \\
\hline $\mathrm{Cr}$ & 1.42 & 0.05 & 3.50 \\
\hline $\mathrm{Cu}$ & 0.0266 & NA & NA \\
\hline $\mathrm{Fe}$ & 0.136 & 0.018 & 13.0 \\
\hline $\mathrm{Gd}$ & 0.0567 & NA & NA \\
\hline $\mathrm{K}$ & 17.6 & 0.7 & 3.91 \\
\hline $\mathrm{La}$ & $<0.0535$ & NA & NA \\
\hline $\mathrm{Li}$ & 0.193 & 0.008 & 3.89 \\
\hline $\mathrm{Mg}$ & $<0.0424$ & NA & NA \\
\hline $\mathrm{Mn}$ & 0.0571 & NA & NA \\
\hline Mo & 0.389 & 0.014 & 3.5 \\
\hline $\mathrm{Na}$ & 3510 & 29 & 0.83 \\
\hline $\mathrm{Ni}$ & $<0.183$ & NA & NA \\
\hline $\mathrm{P}$ & 2.54 & 0.05 & 1.97 \\
\hline $\mathrm{Pb}$ & $<0.275$ & NA & NA \\
\hline $\mathrm{S}$ & 16.9 & 0.6 & 3.50 \\
\hline $\mathrm{Sb}$ & $<0.277$ & NA & NA \\
\hline $\mathrm{Si}$ & 1.78 & 0.05 & 2.81 \\
\hline $\mathrm{Sn}$ & $<0.13000$ & NA & NA \\
\hline $\mathrm{Sr}$ & $<0.0276$ & NA & NA \\
\hline $\mathrm{Ti}$ & $<0.0242$ & NA & $\mathrm{NA}$ \\
\hline $\mathrm{U}$ & $<1.17$ & NA & NA \\
\hline $\mathrm{V}$ & $<0.0484$ & NA & NA \\
\hline $\mathrm{Zn}$ & $<0.0373$ & NA & NA \\
\hline $\mathrm{Zr}$ & $<0.0314$ & NA & NA \\
\hline
\end{tabular}

* The supernate was not diluted 


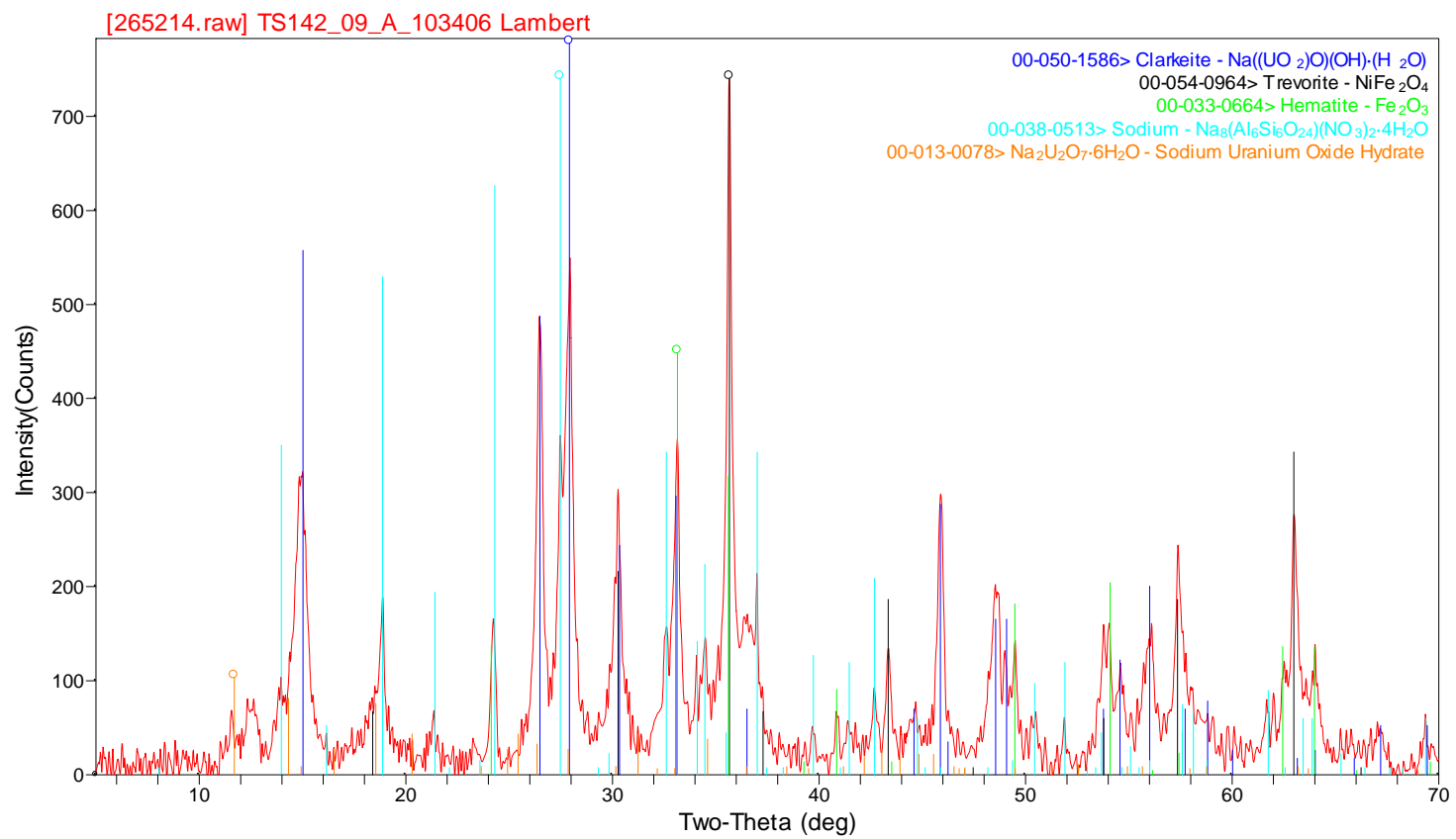

Figure 2-2 - Post Wash Tank 7 Sludge Solids XRD Analysis

The Tank 7 post-wash slurry was filtered and the dried solids were analyzed using XRD. No sodium oxalate or iron oxalate was detected.

\section{Washing Study Methods}

The Tank 7 sludge washing was completed in the SRNL Shielded Cells. The Tank 7 sample was subjected to a series of 10 decants and 9 wash cycles to decrease the concentration of soluble cations and anions. The washing followed the Gillam plan for SB7 ${ }^{13}$. The Shielded Cells technicians work was controlled by a general wash/decant Work Instruction ${ }^{14}$ along with an R\&D instruction specific to each decant/wash cycle.

The following steps were completed for each decant/wash cycle:

1. Weigh Tank 7 slurry bottle, empty decant bottle, and empty slurry sample bottle.

2. Pump approximately $650 \mathrm{~mL}(597-724 \mathrm{~mL})$ of decanted supernate to 1-liter bottle.

3. Weigh full supernate bottle.

4. Sample supernate for analysis (analyze for total supernate solids ${ }^{15}$, density ${ }^{16}$ )

5. Weigh Tank 7 slurry bottle.

6. Add approximately $650 \mathrm{~mL}$ of inhibited water $\left(0.001 \mathrm{M} \mathrm{OH}^{-}, 0.0015 \mathrm{M}\right.$ nitrite $)$ to Tank 7 slurry bottle.

7. Mix slurry for 30 minutes.

8. Pull slurry sample (analyze for total slurry solids ${ }^{15}$, insoluble solids, density ${ }^{16}$ ).

9. Weigh full slurry sample bottle.

10. Prepare diluted supernate samples for IC and ICP-AES analysis and submit samples.

The first decant was large and removed approximately $50 \%$ of the supernate volume and $50 \%$ of the soluble species. After each decant, inhibited water was added, the slurry was mixed 30 minutes, and the slurry was sampled. After settling overnight, the process is repeated for the next decant/wash cycle. 
As washing continued, the concentration of the soluble anions and cations dropped exponentially and can be predicted knowing the supernate volume and the added inhibited water volume.

\section{Equation 1: $\mathbf{X}_{\mathrm{n}}=\mathbf{X}_{\mathrm{n}-1} * \mathbf{V}_{\text {sup }} /\left(\mathbf{V}_{\text {sup }}+\mathbf{V}_{\text {IW }}\right)$}

$\mathrm{Xn}$ is the concentration of cation or anion after wash $\mathrm{n}$

$\mathrm{V}_{\text {sup }}=$ Volume of Supernate after decant $n$

$\mathrm{V}_{\mathrm{IW}}=$ Volume of Added Inhibited Water for wash $\mathrm{n}$

If the wash ratio $(\mathrm{R})$ is defined as

$$
\begin{gathered}
\text { Equation 2: } \mathbf{R}_{\mathbf{n}}=\left(\mathbf{V}_{\text {sup }}+\mathbf{V}_{\text {IW }}\right) / \mathbf{V}_{\text {sup }} \\
X_{n}=X_{n-1} / R_{n} \\
\text { Equation 3: } \mathbf{R}_{\mathbf{n}}=\mathbf{X}_{\mathbf{n - 1}} / \mathbf{X}_{\mathbf{n}}
\end{gathered}
$$

\section{$\underline{\text { Washing Analytical Methods }}$}

Tank 7 supernate was collected with a $0.45 \mu \mathrm{m}$ filter cup from a supernate decant sample in the SRNL Shielded Cells and submitted to AD for ICP-AES and IC. Four separate approximately 1 $\mathrm{mL}$ samples were weighed then diluted to $50 \mathrm{~mL}$ with DI water in volumetric flasks. Two aliquots of diluted supernate were removed from each volumetric flask, one for IC and one for ICP-AES analysis.

Four separate aliquots of the slurry and four separate aliquots of the supernate were analyzed in the Shielded Cells for density ${ }^{16}$ and for total supernate solids ${ }^{15}$. A $\mathrm{pH}$ measurement of the supernate was completed four times using the decant supernate from each decant/wash cycle.

Washing Study Results

The washing of the sludge has three steps. First the settled slurry is decanted to approximately the settled sludge level to maximize the removal of supernate and minimize the number of wash steps required. Second, approximately the same volume inhibited water is added to the slurry and mixed to redissolve the undissolved solids. Third, the slurry solids are allowed to settle in preparation for a subsequent decant. The slurry was sampled after 30 minutes of mixing was complete and the decanted supernate was used for all supernate analyses required. The anion analysis of the supernate is summarized in Table 2-17 and the ICP-AES analysis of the supernate is summarized in Table 2-18. The $\mathrm{pH}$ and solids data are summarized in Table 2-19. 
SRNL-STI-2009-00774

Revision 0

Table 2-17 - Tank 7 Supernate Anion Concentration during Washing, mg/kg

\begin{tabular}{|c|c|c|c|c|c|c|c|c|}
\hline & Wash B & Wash C & Wash D & Wash E & Wash F & Wash G & Wash H & Wash I \\
\hline Fluoride & $<241$ & $<256$ & $<265$ & $<272$ & $<259$ & $<271$ & $<266$ & $<258$ \\
\hline Formate & $<241$ & $<256$ & $<265$ & $<272$ & $<259$ & $<271$ & $<266$ & $<258$ \\
\hline Chloride & $<241$ & $<256$ & $<265$ & $<272$ & $<259$ & $<271$ & $<266$ & $<258$ \\
\hline Nitrite & 12,200 & 7,770 & 5,030 & 3,060 & 2,230 & 1,380 & 929 & 594 \\
\hline Bromide & $<241$ & $<256$ & $<265$ & $<272$ & $<259$ & $<271$ & $<266$ & $<258$ \\
\hline Nitrate & 25,500 & 15,600 & 9,940 & 5,600 & 4,160 & 2,840 & 1,750 & 1,080 \\
\hline Phosphate & $<241$ & $<256$ & $<265$ & $<272$ & $<259$ & $<271$ & $<266$ & $<258$ \\
\hline Sulfate & 1,390 & 869 & 584 & 367 & $<259$ & $<271$ & $<266$ & $<258$ \\
\hline Oxalate & 1,940 & 3,920 & 5,920 & 9,740 & 13,220 & 13,490 & 8,690 & 5,490 \\
\hline
\end{tabular}


Table 2-18 -- Tank 7 Supernate ICP-AES during Washing, mg/L

\begin{tabular}{|c|c|c|c|c|c|c|c|c|}
\hline Sample & Wash B & $\begin{array}{c}\text { Wash } \\
\text { C }\end{array}$ & $\begin{array}{c}\text { Wash } \\
\text { D }\end{array}$ & Wash E & Wash F & $\begin{array}{c}\text { Wash } \\
\text { G }\end{array}$ & $\begin{array}{c}\text { Wash } \\
\text { H }\end{array}$ & Wash I \\
\hline $\mathrm{Ag}$ & $<1.52$ & $<1.58$ & $<1.57$ & $<1.60$ & $<1.51$ & $<1.36$ & $<1.34$ & $<1.34$ \\
\hline $\mathrm{Al}$ & 3,610 & 2,290 & 1,490 & 908 & 582 & 366 & 261 & 175 \\
\hline $\mathrm{B}$ & 38.5 & 24.0 & 14.9 & 9.36 & 5.05 & $<<5.14$ & $<5.05$ & $<5.05$ \\
\hline $\mathrm{Ba}$ & $<3.63$ & $<0.381$ & $<0.379$ & $<0.385$ & $<3.64$ & $<0.377$ & $<0.370$ & $<0.370$ \\
\hline $\mathrm{Be}$ & $<0.867$ & $<0.0526$ & $<0.523$ & $<0.532$ & $<0.503$ & $<0.521$ & $<0.0910$ & $<0.0910$ \\
\hline $\mathrm{Ca}$ & $<2.06$ & 1.84 & $<1.56$ & 1.77 & 1.76 & $<1.06$ & $<1.04$ & 1.52 \\
\hline $\mathrm{Cd}$ & $<0.650$ & $<0.689$ & $<0.685$ & $<0.696$ & $<0.658$ & $<0.682$ & $<0.669$ & $<0.669$ \\
\hline $\mathrm{Ce}$ & $<5.26$ & $<5.48$ & $<5.44$ & $<5.53$ & $<5.23$ & $<<.55$ & $<5.32$ & $<5.32$ \\
\hline $\mathrm{Cr}$ & 47.2 & 29.7 & 19.6 & 12.0 & 7.70 & 5.17 & 3.68 & 2.40 \\
\hline $\mathrm{Cu}$ & $<1.19$ & $<0.638$ & $<0.634$ & $<0.64$ & $<0.609$ & $<0.632$ & $<0.620$ & $<0.620$ \\
\hline $\mathrm{Fe}$ & $<2.60$ & 0.891 & $<2.24$ & 0.584 & $<0.561$ & 0.764 & $<0.570$ & 0.778 \\
\hline $\mathrm{Gd}$ & $<2.49$ & $<1.30$ & $<1.30$ & $<1.32$ & $<1.25$ & $<1.29$ & $<1.27$ & $<1.27$ \\
\hline $\mathrm{K}$ & 670 & 431 & 276 & 168 & 104 & $<75.4$ & 41.3 & 27.3 \\
\hline $\mathrm{La}$ & $<2.17$ & $<0.683$ & $<0.679$ & $<0.690$ & $<0.652$ & $<1.12$ & $<0.664$ & $<0.664$ \\
\hline $\mathrm{Li}$ & $<4.44$ & $<1.16$ & $<1.15$ & $<1.17$ & $<1.11$ & $<1.15$ & $<1.12$ & $<1.12$ \\
\hline $\mathrm{Mg}$ & $<1.08$ & $<0.286$ & $<0.284$ & $<0.286$ & $<0.273$ & $<0.283$ & $<0.277$ & 0.296 \\
\hline $\mathrm{Mn}$ & $<1.14$ & $<0.480$ & $<0.477$ & $<0.485$ & $<0.458$ & $<0.301$ & $<0.295$ & 0.297 \\
\hline Mo & 15.7 & 9.96 & 6.23 & $<3.54$ & $<2.49$ & $<<2.77$ & $<2.35$ & $<2.35$ \\
\hline $\mathrm{Na}$ & 59,500 & 38,500 & 27,400 & 20,300 & 16,800 & 13,500 & 8770 & 5730 \\
\hline $\mathrm{Ni}$ & $<4.93$ & $<5.16$ & $<5.13$ & $<5.21$ & $<4.93$ & $<5.11$ & $<5.01$ & $<5.01$ \\
\hline $\mathrm{P}$ & 92.8 & 52.3 & 34.7 & $<21.1$ & 15.2 & $<<15.4$ & $<15.1$ & $<15.1$ \\
\hline $\mathrm{Pb}$ & $<7.48$ & $<7.79$ & $<7.74$ & $<7.87$ & $<7.44$ & $<7.71$ & $<7.57$ & $<7.57$ \\
\hline $\mathrm{S}$ & 613 & $<423$ & $<219$ & $<168$ & $<145$ & $<168$ & $<148$ & $<148$ \\
\hline $\mathrm{Sb}$ & $<14.0$ & $<7.79$ & $<7.74$ & $<7.87$ & $<13.9$ & $<9.44$ & $<7.57$ & $<7.57$ \\
\hline $\mathrm{Si}$ & $<12.9$ & $<6.72$ & $<6.68$ & 3.67 & $<6.42$ & $<6.65$ & $<6.53$ & $<6.53$ \\
\hline $\mathrm{Sn}$ & $<3.52$ & $<3.68$ & $<3.66$ & $<3.72$ & $<3.52$ & $<<3.64$ & $<3.58$ & $<3.58$ \\
\hline $\mathrm{Sr}$ & $<0.542$ & $<0.0610$ & $<0.0606$ & $<0.0616$ & $<0.582$ & $<0.060$ & $<0.0592$ & $<0.0592$ \\
\hline $\mathrm{Ti}$ & $<2.22$ & $<0.234$ & $<0.233$ & $<0.690$ & $<2.24$ & $<0.676$ & $<0.228$ & $<0.228$ \\
\hline $\mathrm{U}$ & $<31.7$ & $<33.0$ & $<32.8$ & $<33.4$ & $<31.5$ & $<32.7$ & $<35.6$ & $<35.6$ \\
\hline $\mathrm{V}$ & $<2.60$ & $<0.683$ & $<0.679$ & $<0.690$ & $<0.65$ & $<0.68$ & $<0.664$ & $<0.664$ \\
\hline $\mathrm{Zn}$ & $<1.12$ & $<0.431$ & $<1.049$ & $<0.410$ & $<0.387$ & $<0.401$ & $<1.03$ & $<1.03$ \\
\hline $\mathrm{Zr}$ & $<1.19$ & $<0.444$ & $<0.441$ & $<0.448$ & $<0.424$ & $<0.439$ & $<0.431$ & $<0.431$ \\
\hline
\end{tabular}


Table 2-19 - Tank 7 pH, Solids and Density during Washing

\begin{tabular}{|c|c|c|c|c|c|c|}
\hline & $\begin{array}{c}\text { Slurry } \\
\text { Density, } \\
\text { g/ml }\end{array}$ & $\begin{array}{c}\text { Supernate } \\
\text { Density, } \\
\text { g/ml }\end{array}$ & $\begin{array}{c}\text { Measured } \\
\text { Total } \\
\text { Solids, } \\
\mathbf{w t} \%\end{array}$ & $\begin{array}{c}\text { Calculated } \\
\text { Insoluble } \\
\text { Solids, } \\
\mathbf{w t} \%\end{array}$ & $\begin{array}{c}\text { Measured } \\
\text { Dissolved } \\
\text { Solids, } \\
\mathbf{w t} \text { \% }\end{array}$ & pH \\
\hline B & 1.22 & 1.12 & 26.2 & 14.1 & 14.0 & 13.5 \\
\hline C & 1.19 & 1.11 & 22.0 & 14.0 & 9.32 & 13.4 \\
\hline D & 1.15 & 1.06 & 19.5 & 13.5 & 6.97 & 13.4 \\
\hline E & 1.14 & 1.05 & 16.6 & 11.9 & 5.31 & 13.3 \\
\hline F & 1.13 & 1.04 & 14.3 & 10.3 & 4.44 & 13.1 \\
\hline G & 1.11 & 1.03 & 12.3 & 8.91 & 3.66 & NA \\
\hline H & 1.09 & 1.02 & 10.8 & $8.42 *$ & 2.56 & 12.9 \\
\hline I & 1.08 & 1.02 & 9.80 & 8.49 & 1.42 & 12.7 \\
\hline
\end{tabular}

* Used three of four total solids results as the fourth result was approximately $20 \%$ low.

\section{Particle size Results}

The as-received and post-wash slurry was diluted with supernate simulant to dilute the solids as needed for particle size analysis. The simulant is designed to match the composition of the supernate to ensure that no dissolution of undissolved solids occurs as the result of the dilution. The particle size was measured using a Microtrac X-100 Laser Diffraction Analyzer. The composition of the supernate simulants is summarized in Table 2-20. The particles size results are summarized in Table 2-21.

Table 2-20 - Supernate Simulant for Particle Size Dilution

\begin{tabular}{|l|c|c|c|c|c|}
\hline & & \multicolumn{2}{|c|}{ As-Received } & \multicolumn{2}{c|}{ After Washing } \\
\hline Recipe & $\mathbf{M W}$ & $\mathbf{M}$ & Add, $\mathbf{g} / \mathbf{L}$ & $\mathbf{M}$ & $\begin{array}{c}\text { Add, } \\
\text { g/L }\end{array}$ \\
\hline $\mathrm{KOH}$ & 56.1056 & 0.027 & 1.521 & 0.00045 & 0.025 \\
\hline $\mathrm{NaOH}$ & 39.9771 & 1.653 & 66.078 & 0.00007 & 0.003 \\
\hline $\mathrm{NaAlO}_{2}$ & 81.97 & 0.197 & 16.162 & 0.00430 & 0.352 \\
\hline $\mathrm{Na}_{2} \mathrm{SO}_{4}$ & 322.18 & 0.028 & 9.073 & 0.00050 & 0.161 \\
\hline $\mathrm{NaNO}_{2}$ & 68.9953 & 0.496 & 34.216 & 0.00860 & 0.593 \\
\hline $\mathrm{NaNO}_{3}$ & 84.9947 & 0.691 & 58.699 & 0.01160 & 0.986 \\
\hline $\mathrm{Na}_{3} \mathrm{PO}_{4}$ & 380.11 & 0.004 & 1.367 & 0.00050 & 0.190 \\
\hline $\mathrm{Na}_{2} \mathrm{C}_{2} \mathrm{O} 4$ & 133.9991 & 0.013 & 1.781 & 0.04140 & 5.548 \\
\hline $\mathrm{Na}_{2} \mathrm{CO}_{3}$ & 105.9884 & 0.027 & 2.831 & 0.00052 & 0.055 \\
\hline
\end{tabular}

Table 2-21 - Tank 7 Particle Size Results, microns

\begin{tabular}{|c|c|c|}
\hline Sample & $\begin{array}{c}\text { Particle size, } \\
\text { number average }\end{array}$ & $\begin{array}{c}\text { Particle size, } \\
\text { volume average }\end{array}$ \\
\cline { 1 - 2 } As-received & \multicolumn{2}{|c|}{ To be added in Rev 1.} \\
\hline Post-wash & \\
\hline
\end{tabular}


$\underline{\text { Rheology Methods and results }}$

Rheological properties of radioactive samples are determined using a Haake M5/RV30 rotoviscometer. The M5/RV30 is a Searle sensor system, where the bob rotates and the cup is fixed. The torque and rotational speed of the bob are measured. Heating/cooling of the cup/sample/bob is through the holder that holds the cup. The shear stress is determined from the torque measurement and is independent of the rheological properties. Conditions that impact the measured torque are; slip (material does not properly adhere to the rotor or cup), phase separation (buildup of a liquid layer on the rotor), sedimentation (particles settling out of the shearing zone), homogeneous sample (void of air), lack of sample (gap not filled), excess sample (primarily impacts rheologically thin fluids), completely filling up the void below the bob (air buffer that is now filled with fluid) and Taylor vortices. The first five items yield lower stresses and the last three add additional stresses.

The shear rate is geometrically determined using the equations of change (continuity and motion) and is that for a Newtonian fluid. This assumption also presupposes that the flow field is fully developed and the flow is laminar. The shear rate can be calculated for a non-Newtonian fluid using the measured data and fitting these data to the rheological model or corrected as recommended by Darby ${ }^{17}$. In either case, for shear thinning non-Newtonian fluids typical of Savannah River Site (SRS) sludge wastes, the corrected shear rates are greater than their corresponding Newtonian shear rates, resulting in a thinner fluid. Correcting the flow curves was not performed in this task; therefore, the results are biased high.

The bob typically used for measuring tank sludge is the MV I rotor. The shape, dimensions, and geometric constants for the MV I rotor is provided in Table 2-22. Prior to performing the measurements, the rotors and cups were inspected for physical damage. The torque/speed sensors and temperature bath verified for functional operability using a bob/cup combination with a National Institute of Standards and Technology (NIST) traceable Newtonian oil standard, using the MV I rotor. The resulting flow curves were then fitted as a Newtonian fluid and this calculated viscosity must be within $\pm 10 \%$ of the reported NIST viscosity at a given temperature for the system to be considered functionally operable. A N10 oil standard was used to verify system operability prior to the sludge measurements. The flow curves for the sludge are fitted to the down curves using the Bingham Plastic rheological model, Equation (1), where $\tau$ is the measured stress $(\mathrm{Pa}), \tau_{\mathrm{o}}$ is the Bingham Plastic yield stress $(\mathrm{Pa}), \mu_{\infty}$ is the plastic viscosity $(\mathrm{Pa} \cdot \mathrm{sec})$, and $\gamma_{\text {is }}$ the measured shear rate $\left(\mathrm{sec}^{-1}\right)$. During all these measurements, the sample remained in the cup for the 2 nd measurement, due to the limited sample availability.

Equation 4: $\tau=\tau_{\mathrm{o}}+\boldsymbol{\mu}_{\infty} \gamma$ 
SRNL-STI-2009-00774

Revision 0

Table 2-22 - Rheology Specifications and Flow Curve Program

\begin{tabular}{|l|l|}
\hline \multicolumn{2}{|l|}{ Dimensions and Flow Curve Program } \\
\hline Rotor Type & MV I \\
\hline Rotor radius - Ri $(\mathrm{mm})$ & 20.04 \\
\hline Cup Radius - $\mathrm{Ra}(\mathrm{mm})$ & 21.0 \\
\hline Height of rotor -L (mm) & 60 \\
\hline Sample Volume (cm) minimum & 40 \\
\hline A factor (Pa/\%torque) & 3.22 \\
\hline M factor (s-1/\%RPM) & 11.7 \\
\hline Shear rate range (s-1) & $0-600$ \\
\hline Ramp up time (min) & 5 \\
\hline Hold time (min) & 1 \\
\hline Ramp down time (min) & 5 \\
\hline
\end{tabular}

The rheology of the slurry is a very thin with virtually no yield stress. The slurry undissloved solids settle very quickly, allowing subsequent washing cycles to be completed each day. For rapidly settling slurries, it can be hard to measure the yield stress of the slurry so this result may be closer to the supernate result than the slurry. The results are summarized in Table 2-23.

Table 2-23 - Tank 7 Slurry Rheology

\begin{tabular}{|c|c|c|}
\hline Sample & $\begin{array}{c}\text { Plastic Viscosity } \\
\text { (cP) }\end{array}$ & $\begin{array}{c}\text { Yield Stress } \\
\text { (Pa) }\end{array}$ \\
\hline As-received & 3.5 & $\sim 0.0$ \\
\hline Post-wash & 3.3 & $\sim 0.0$ \\
\hline
\end{tabular}

\subsection{Discussion}

The following section discusses the sludge washing, oxalate removal, elemental ratios, rheology, and optimum washing strategy for Tank 7.

Sludge Washing

The Tank 7 sludge was subjected to a series of 10 decants and 9 wash cycles to decrease the concentration of soluble cations and anions. The first decant was large and removed approximately $50 \%$ of the supernate volume and $50 \%$ of the soluble species. After each decant, inhibited water was added, the slurry was mixed for at least 30 minutes, and the slurry was sampled. After settling overnight, the process is repeated for the next decant/wash cycle.

A mass balance was used to track the volume and mass of the slurry during washing. Using the measured insoluble solids and density of supernate for each wash cycle, the volume of supernate can be calculated. The mass of wash water added in each wash cycle was measured and its volume was calculated. The volume of after washing divided by the volume before washing was calculated and these data are summarized in Table 3-1. The calculated concentration ratios for the soluble species are summarized in Table 3-2. 
Table 3-1 Calculated Volume and Volume Ratio Data during Washing

\begin{tabular}{|c|c|c|c|}
\hline $\begin{array}{c}\text { Wash } \\
\text { Cycle }\end{array}$ & $\begin{array}{c}\text { Volume Supernate } \\
\text { after decant, mL }\end{array}$ & $\begin{array}{c}\text { Volume supernate } \\
\text { after wash, mL }\end{array}$ & $\begin{array}{c}\text { Volume } \\
\text { Ratio }\end{array}$ \\
\hline A & 1,248 & 1,910 & 1.53 \\
\hline B & 1,223 & 1,912 & 1.56 \\
\hline C & 1,318 & 1,908 & 1.45 \\
\hline D & 1,231 & 1,971 & 1.60 \\
\hline E & 1,219 & 1,908 & 1.56 \\
\hline F & 1,231 & 1,922 & 1.56 \\
\hline G & 1,253 & 1,959 & 1.56 \\
\hline H & 1,198 & 1,891 & 1.58 \\
\hline I & 1,263 & 1,936 & 1.53 \\
\hline
\end{tabular}

Table 3-2 Calculated Concentration Ratios Data during Washing

\begin{tabular}{|c|c|c|c|cc|c|c|c|c|c|}
\hline $\begin{array}{c}\text { Wash } \\
\text { Cycle }\end{array}$ & $\begin{array}{c}\text { Nitrate } \\
\text { Ratio }\end{array}$ & $\begin{array}{c}\text { Nitrite } \\
\text { Ratio }\end{array}$ & $\begin{array}{c}\text { Sulfate } \\
\text { Ratio }\end{array}$ & $\begin{array}{c}\text { Oxalat } \\
\text { e Ratio }\end{array}$ & $\begin{array}{c}\text { Na } \\
\text { Ratio }\end{array}$ & $\begin{array}{c}\text { Al } \\
\text { Ratio }\end{array}$ & $\begin{array}{c}\text { B } \\
\text { Ratio }\end{array}$ & $\begin{array}{c}\text { K } \\
\text { Ratio }\end{array}$ & $\begin{array}{c}\text { S } \\
\text { Ratio }\end{array}$ & $\begin{array}{c}\text { P } \\
\text { Ratio }\end{array}$ \\
\hline B & 1.64 & 1.57 & 1.60 & 0.49 & 1.52 & 1.58 & 1.60 & 1.55 & 1.45 & 1.77 \\
\hline C & 1.57 & 1.55 & 1.49 & 0.66 & 1.45 & 1.54 & 1.62 & 1.56 & 2.02 & 1.51 \\
\hline D & 1.66 & 1.64 & 1.59 & 0.61 & 1.60 & 1.64 & 1.59 & 1.64 & 1.24 & NA \\
\hline E & 1.44 & 1.37 & 1.41 & 0.74 & 1.52 & 1.57 & NA & 1.62 & 1.16 & NA \\
\hline F & 1.47 & 1.62 & NA & 0.98 & 1.52 & 1.57 & NA & NA & NA & NA \\
\hline G & 1.62 & 1.49 & NA & 1.55 & NA & NA & NA & NA & NA & NA \\
\hline H & 1.62 & 1.56 & NA & 1.58 & NA & NA & NA & NA & NA & NA \\
\hline I & 1.83 & 1.67 & NA & 1.50 & NA & NA & NA & NA & NA & NA \\
\hline
\end{tabular}

A graph of the wash ratios $\left(R_{n}\right)$ versus decant cycle should give the same ratio for each soluble species (Figure 3-1). This is true for all measured soluble species (until the species concentration approaches its analytical detection limit) except oxalate.

Overall, the concentration of the soluble species decreased by a factor of 51.3 as a result of the washing. 


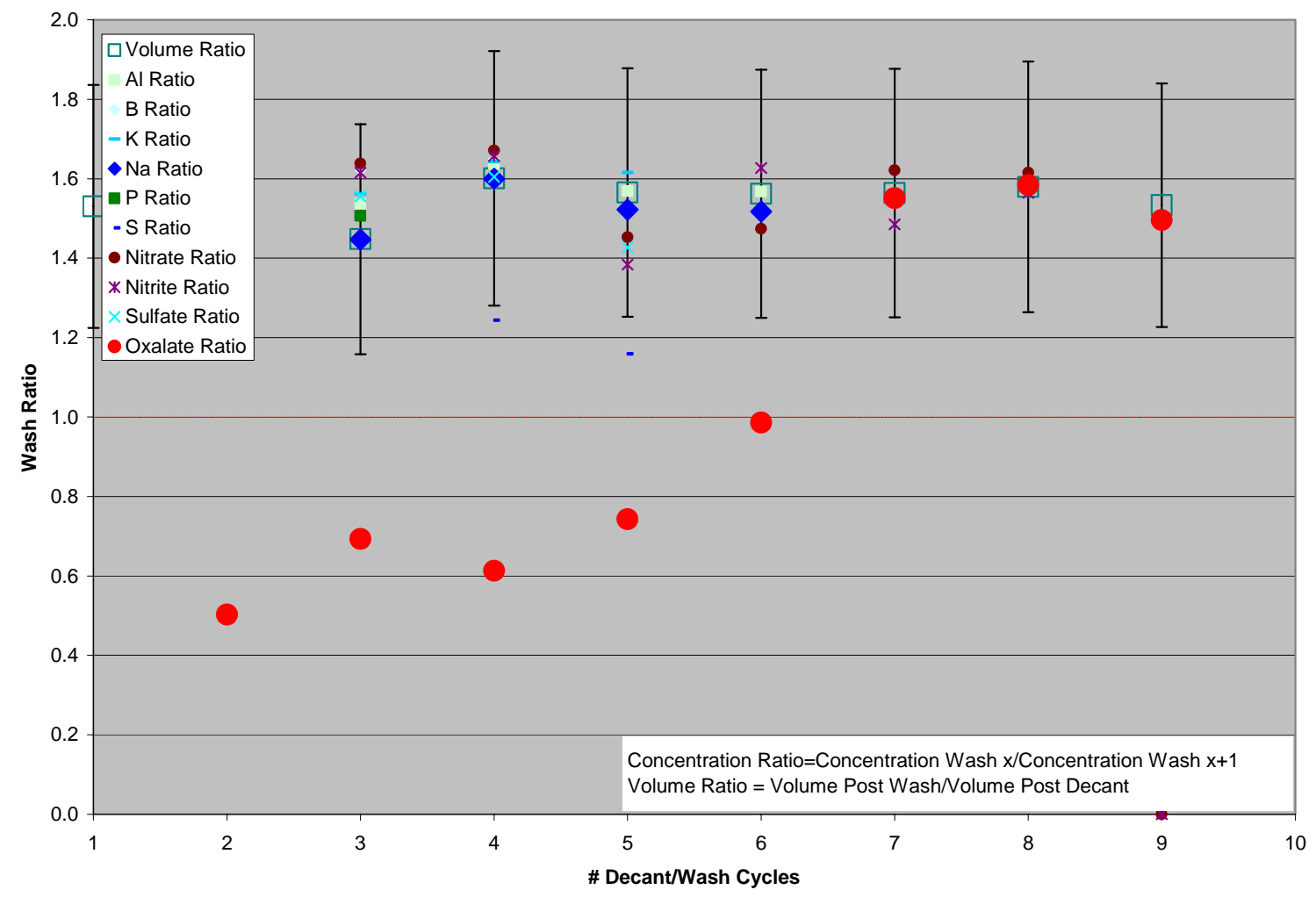

Figure 3-1 - Volume and Concentration Wash Ratios (R) throughout Washing

The overall wash ratio can also be calculated using the as-received and post-wash sample results. The results for soluble cations and anions are summarized in Table 3-3. As can be seen from these data, the wash ratio varies from 48.4 to 72.4 . Using $\mathrm{Al}, \mathrm{B}, \mathrm{Cr}, \mathrm{K} \mathrm{P}$ and $\mathrm{S}$ to calculate an average wash ratio yields 51.8. This agrees well with the 51.3 ratio predicted by the wash and decant volumes.

The overall wash ratio can also be calculated using the as-received and post-wash sample results. The results for soluble cations and anions are summarized in Table 3-3. As can be seen from these data, the wash ratio varies from 48.4 to 72.4 . Using $\mathrm{Al}, \mathrm{B}, \mathrm{Cr}, \mathrm{K} \mathrm{P}$ and S to calculate an average wash ratio yields 51.8. This agrees well with the 51.3 ratio calculated using the wash and decant volumes. 
SRNL-STI-2009-00774

Revision 0

Table 3-3 - Determination of Overall Wash Ratio for Slurry

\begin{tabular}{|c|c|c|c|}
\hline $\begin{array}{l}\text { Anion or } \\
\text { Element }\end{array}$ & $\begin{array}{c}\text { As- } \\
\text { Received } \\
\mathrm{mg} / \mathrm{L}^{\wedge}\end{array}$ & $\begin{array}{c}\text { Post } \\
\text { Wash } \\
\mathrm{mg} / \mathrm{L} \\
\end{array}$ & $\begin{array}{l}\text { Wash } \\
\text { Ratio }\end{array}$ \\
\hline Nitrite & 22,800 & 355 & 65.2 \\
\hline Nitrate & 42,900 & 592 & 72.4 \\
\hline Sulfate & 2,340 & $<50$ & $>46.8$ \\
\hline Oxalate & 1,170 & 3,295 & 0.355 \\
\hline $\mathrm{Al}$ & 5,320 & 110 & 48.4 \\
\hline $\mathrm{B}$ & 56.4 & 1.03 & 54.8 \\
\hline $\mathrm{Cr}$ & 69.3 & 1.42 & 48.8 \\
\hline $\mathrm{K}$ & 1060 & 17.6 & 60.2 \\
\hline Mo & 23.0 & 0.389 & 59.1 \\
\hline $\mathrm{Na}$ & 88,000 & 3510 & 25.0 \\
\hline $\mathrm{P}$ & 136.7 & 2.54 & 53.8 \\
\hline $\mathrm{S}$ & 903 & 16.9 & 53.4 \\
\hline
\end{tabular}

$\wedge$ Calculated by multiplying anion concentration $(\mathrm{mg} / \mathrm{kg}) * 1.17 \mathrm{~kg} / \mathrm{L}$

Oxalate Removal

The Tank 7 as-received sample contained oxalate only as sodium oxalate. No iron oxalate was detected in the as-received or post-wash Tank 7 sample based on XRD analysis. It was expected that some iron oxalate would be present in the as-received sample as oxalic acid was added to dissolve sludge remaining in Tanks 5 and 6 . Approximately $95 \%$ of the sodium oxalate was undissolved in the as-received sample since its concentration exceeded solubility (Table 3-4). The true insoluble solids concentration of the incoming sample was $3.704 \mathrm{wt} \%$ with $2.620 \mathrm{wt} \%$ undissolved sodium oxalate present in the filtered solids.

The TOC analysis is another potential measure of oxalate. The TOC concentration of sludge samples is generally low, so most of the TOC in the as-received sample was likely oxalate. If all of the TOC is oxalate, the as-received sample was $20,400 \mathrm{mg} / \mathrm{kg}$ oxalate, approximately $13 \%$ higher than the actual measurement. This is an independent measurement confirming that the oxalate concentration is likely approximately $18,100 \mathrm{mg} / \mathrm{kg}$ as measured.

Table 3-4 - As-Received Tank 7 Oxalate Balance

\begin{tabular}{|l|c|c|c|}
\hline Analysis & Tank 7 & Mass, g & \% by mass \\
\hline TOC if Oxalate & $20,400 \mathrm{mg} / \mathrm{kg}$ & 75.11 & 113 \\
\hline Total Oxalate & $18,100 \mathrm{mg} / \mathrm{kg}$ & 66.65 & 100 \\
\hline Supernate Oxalate & $1,000 \mathrm{mg} / \mathrm{kg}$ & 3.43 & 5 \\
\hline Undissolved Oxalate & & 63.22 & 95 \\
\hline Undissolved Sodium Oxalate & $2.620 \mathrm{wt} \%$ & 96.24 & \\
\hline Insoluble Solids (without oxalate) & $3.704 \mathrm{wt} \%$ & & \\
\hline
\end{tabular}

Because most of the sodium oxalate in the as-received sample is undissolved, the oxalate has a very different concentration profile than the soluble anions and cations which are all dropping in concentration from one wash to the next while the supernate oxalate concentration is rising (Figure 3-1). The sodium concentration decreases approximately exponentially as predicted by 
the wash ratio while the oxalate concentration continues to climb until decant/wash cycle 7 , after which it declines exponentially. Also graphed is the prediction by Gillam ${ }^{13}$ based on measured oxalate solubility data developed by Kilpatrick. ${ }^{18}$

Note that oxalate is the only anion that did not follow the washing curve and the only potentially soluble anion that redissolved during washing. Sodium oxalate is the last soluble species to be dissolved during washing of sludge with inhibited water.

After washing was complete, the total oxalate concentration was $1,310 \mathrm{mg} / \mathrm{kg}$ and the supernate oxalate concentration was $3,340 \mathrm{mg} / \mathrm{kg}$ supernate basis $(3,080 \mathrm{mg} / \mathrm{kg}$ slurry basis). The measured slurry oxalate number is $39.2 \%$ of the supernate oxalate (Table $3-5$ ). The oxalate concentration in the slurry this is likely underreported. The slurry is undergoes an aggressive digestion step using $\mathrm{HCl}$ and $\mathrm{HNO}_{3}$ to ensure any undissolved oxalate is dissolved. The digested sample is analyzed within 24 hours and protected from light to minimize decomposition of the oxalate. The oxalate likely decomposed before analysis leading to underreporting of oxalate in the slurry sample.

Table 3-5 - Post-Wash Tank 7 Oxalate Balance

\begin{tabular}{|l|c|c|}
\hline Analysis & $\begin{array}{c}\text { Tank 7 } \\
\mathbf{m g} / \mathbf{k g}\end{array}$ & \% by mass \\
\hline Total Oxalate & 1,310 & $100 \%$ \\
\hline Supernate Oxalate & 3,080 & $235 \%$ \\
\hline
\end{tabular}

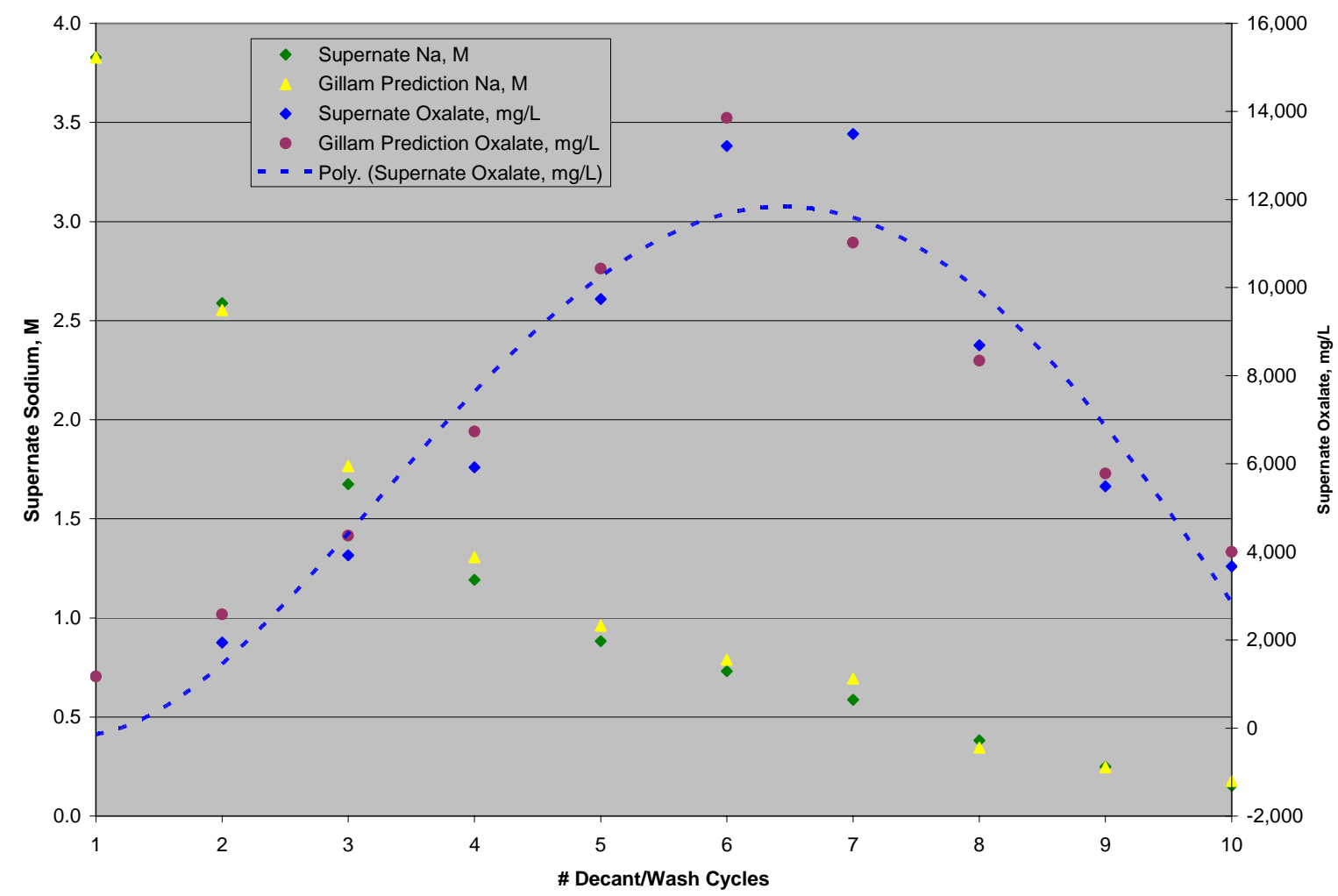

Figure 3-2 - Sodium, $M$ and Oxalate, mg/L Profile throughout Washing 
The \% removal of the various anions can be calculated and compared to oxalate. Soluble oxalate is removed via washing at the same rate as the others anions. However, in each wash step, some of the undissolved sodium oxalate is redissolved and can be removed by decanting a portion of the supernate.

For example, as received there are $2650 \mathrm{~mL}$ of supernate. The first task in the decant/wash cycle is to decant $1394 \mathrm{~mL}$ of supernate from the slurry. The remaining supernate in the slurry is 1256 $\mathrm{mL}$ so $52.6 \%$ of the supernate has been removed. For any species that is totally soluble, $52.6 \%$ of that cation or anion has been removed. The volume ratio (Table 3-1) is used to calculate the original supernate volume remaining after each wash step. For example, the remaining supernate after wash $\mathrm{A} /$ decant $\mathrm{B}$ is $1256 \mathrm{~mL} / 1.53=821 \mathrm{~mL}$. The cumulative removal is $(1-821 / 2650)$ $* 100 \%=69.0 \%$. Therefore column B of Table 3-6is the expected result for any anion or cation that is totally soluble.

For oxalate and sodium a mass balance was used to determine the $\%$ of sodium and oxalate that were removed. Only the soluble sodium oxalate is removed via washing at the same rate as the others anions. However, in each wash step, some of the undissolved sodium oxalate is redissolved and can be removed by decanting a portion of the supernate. Note that after 5 washes, $91.9 \%$ of the soluble species have been removed while only $40.3 \%$ of the oxalate has been removed. Column C and D of Table 3-6 are the calculated removal percentages for oxalate and sodium respectively.

Table 3-6 - Cumulative Percent Removal of Soluble Ions and Oxalate during Slurry Washing

\begin{tabular}{|c|c|c|c|}
\hline Decant/Wash Cycle & \% anions/cations removed & \% oxalate removed & \% sodium removed \\
\hline B or 2 & $69.0 \%$ & $10.0 \%$ & $63.1 \%$ \\
\hline C or 3 & $80.2 \%$ & $16.5 \%$ & $72.1 \%$ \\
\hline D or 4 & $86.3 \%$ & $28.1 \%$ & $79.3 \%$ \\
\hline E or 5 & $91.4 \%$ & $40.3 \%$ & $85.0 \%$ \\
\hline F or 6 & $94.5 \%$ & $54.9 \%$ & $89.3 \%$ \\
\hline G or 7 & $96.5 \%$ & $69.6 \%$ & $92.6 \%$ \\
\hline H or 8 & $97.8 \%$ & $80.2 \%$ & $95.1 \%$ \\
\hline I or 9 & $98.6 \%$ & $85.8 \%$ & $96.4 \%$ \\
\hline J or 10 & $99.1 \%$ & $89.2 \%$ & $97.2 \%$ \\
\hline
\end{tabular}

Elemental Ratios

The as-received sample can be compared to the post-wash sample to determine whether any of the elements were removed during washing. If a cation is insoluble (such as nickel), the iron to nickel ratio will be the same in the as-received sample (6.10) as it is after the washing is complete (6.03). The iron to element ratios are summarized in column 3 for the as-received sample and column 7 for the post-wash sample in Table 3-7.

Also, the composition of these elements in the post-wash sample can be predicted by the following equation. The results are summarized in column 4 of Table 3-7

Predicted Composition $=\mathrm{Fe}_{\mathrm{PW}} * \mathrm{El}_{\mathrm{AR}} / \mathrm{Fe}_{\mathrm{AR}}=1.99 \mathrm{E}+01 / 4.38 \mathrm{E}+00 * \mathrm{El}_{\mathrm{AR}}=4.54 * \mathrm{El}_{\mathrm{AR}}$ where $\mathrm{El}_{\mathrm{AR}}$ is the as-received composition of any element. 
Knowing the predicted composition, a "\% of predicted" can be calculated as a ratio of measured post-wash divided by predicted post-wash and are summarized in column 5 of Table 3-7. If the element is insoluble, the \% prediction should be between $80-120 \%$. Thus $\mathrm{Ba}, \mathrm{Ca}, \mathrm{Cd}, \mathrm{Cu}, \mathrm{Fe}, \mathrm{Hg}$, $\mathrm{La}, \mathrm{Li}, \mathrm{Mg}, \mathrm{Mn}, \mathrm{Ni}, \mathrm{Pb}, \mathrm{Si}, \mathrm{Sr}, \mathrm{Ti}, \mathrm{U}$ and $\mathrm{Zn}$ were virtually insoluble throughout the washing. For elements such as $\mathrm{Al}, \mathrm{Cr}, \mathrm{K}, \mathrm{Na}, \mathrm{P}$, and $\mathrm{Zr}$, much of these elements were soluble. Had an element been completely soluble, then $99.1 \%$ of that element would be removed during washing. For sodium and potassium, $97 \%$ of the K and $94 \%$ of the Na were removed during washing.

Table 3-7 - Iron to Elemental Ratios and Predicted Post-Wash Composition

\begin{tabular}{|c|c|c|c|c|c|c|}
\hline & \multicolumn{2}{|c|}{ As-Received } & \multicolumn{4}{c|}{ Post-Wash } \\
\hline Element & $\begin{array}{c}\text { Measured } \\
\text { Wt\% }\end{array}$ & $\begin{array}{c}\text { Fe:Element } \\
\text { Ratio }\end{array}$ & $\begin{array}{c}\text { Predicted, } \\
\text { wt \% }\end{array}$ & $\begin{array}{c}\text { \% } \\
\text { prediction }\end{array}$ & $\begin{array}{c}\text { Measured } \\
\text { Wt\% }\end{array}$ & $\begin{array}{c}\text { Fe:Element } \\
\text { Ratio }\end{array}$ \\
\hline $\mathrm{Al}$ & $2.58 \mathrm{E}+00$ & 1.70 & $1.17 \mathrm{E}+01$ & $37 \%$ & $4.30 \mathrm{E}+00$ & 4.63 \\
\hline $\mathrm{Ba}$ & $2.79 \mathrm{E}-02$ & 157 & $1.27 \mathrm{E}-01$ & $103 \%$ & $1.30 \mathrm{E}-01$ & 153 \\
\hline $\mathrm{Ca}$ & $2.04 \mathrm{E}-01$ & 21.5 & $9.27 \mathrm{E}-01$ & $107 \%$ & $9.90 \mathrm{E}-01$ & 20.1 \\
\hline $\mathrm{Cd}$ & $1.76 \mathrm{E}-02$ & 249 & $8.00 \mathrm{E}-02$ & $104 \%$ & $8.35 \mathrm{E}-02$ & 238 \\
\hline $\mathrm{Ce}$ & $3.47 \mathrm{E}-02$ & 126 & $1.58 \mathrm{E}-01$ & $245 \%$ & $3.86 \mathrm{E}-01$ & 51.6 \\
\hline $\mathrm{Cr}$ & $3.87 \mathrm{E}-02$ & 113 & $1.76 \mathrm{E}-01$ & $39 \%$ & $6.80 \mathrm{E}-02$ & 293 \\
\hline $\mathrm{Cu}$ & $1.21 \mathrm{E}-02$ & 362 & $5.50 \mathrm{E}-02$ & $107 \%$ & $5.90 \mathrm{E}-02$ & 337 \\
\hline $\mathrm{Fe}$ & $4.38 \mathrm{E}+00$ & 1.00 & $1.99 \mathrm{E}+01$ & $100 \%$ & $1.99 \mathrm{E}+01$ & 1.00 \\
\hline $\mathrm{Hg}$ & $4.92 \mathrm{E}-02$ & 89.0 & $2.24 \mathrm{E}-01$ & $80 \%$ & $1.78 \mathrm{E}-01$ & 110 \\
\hline $\mathrm{K}$ & $4.59 \mathrm{E}-01$ & 9.54 & $2.09 \mathrm{E}+00$ & $3 \%$ & $6.40 \mathrm{E}-02$ & 311 \\
\hline $\mathrm{La}$ & $1.41 \mathrm{E}-02$ & 311 & $6.41 \mathrm{E}-02$ & $115 \%$ & $7.34 \mathrm{E}-02$ & 271 \\
\hline $\mathrm{Li}$ & $1.48 \mathrm{E}-02$ & 296 & $6.72 \mathrm{E}-02$ & $106 \%$ & $7.15 \mathrm{E}-02$ & 278 \\
\hline $\mathrm{Mg}$ & $1.15 \mathrm{E}-01$ & 38.1 & $5.22 \mathrm{E}-01$ & $115 \%$ & $6.03 \mathrm{E}-01$ & 33.0 \\
\hline $\mathrm{Mn}$ & $9.23 \mathrm{E}-01$ & 4.75 & $4.19 \mathrm{E}+00$ & $103 \%$ & $4.30 \mathrm{E}+00$ & 4.63 \\
\hline $\mathrm{Na}$ & $3.18 \mathrm{E}+01$ & 0.14 & $1.44 \mathrm{E}+02$ & $6 \%$ & $9.20 \mathrm{E}+00$ & 2.16 \\
\hline $\mathrm{Ni}$ & $7.18 \mathrm{E}-01$ & 6.10 & $3.26 \mathrm{E}+00$ & $101 \%$ & $3.30 \mathrm{E}+00$ & 6.03 \\
\hline $\mathrm{P}$ & $7.46 \mathrm{E}-02$ & 58.7 & $3.39 \mathrm{E}-01$ & $38 \%$ & $1.30 \mathrm{E}-01$ & 153 \\
\hline $\mathrm{Pb}$ & $9.43 \mathrm{E}-03$ & 465 & $4.28 \mathrm{E}-02$ & $91 \%$ & $3.90 \mathrm{E}-02$ & 510 \\
\hline $\mathrm{Si}$ & $5.89 \mathrm{E}-01$ & 7.44 & $2.68 \mathrm{E}+00$ & $120 \%$ & $3.20 \mathrm{E}+00$ & 6.22 \\
\hline $\mathrm{Sr}$ & $1.35 \mathrm{E}-02$ & 324 & $6.13 \mathrm{E}-02$ & $112 \%$ & $6.90 \mathrm{E}-02$ & 288 \\
\hline $\mathrm{Ti}$ & $7.35 \mathrm{E}-03$ & 596 & $3.34 \mathrm{E}-02$ & $89 \%$ & $2.96 \mathrm{E}-02$ & 672 \\
\hline $\mathrm{U}$ & $2.04 \mathrm{E}+00$ & 2.15 & $9.27 \mathrm{E}+00$ & $112 \%$ & $1.04 \mathrm{E}+01$ & 1.91 \\
\hline $\mathrm{Zn}$ & $1.65 \mathrm{E}-02$ & 265 & $7.50 \mathrm{E}-02$ & $109 \%$ & $8.20 \mathrm{E}-02$ & 243 \\
\hline $\mathrm{Zr}$ & $6.54 \mathrm{E}-02$ & 67.0 & $2.97 \mathrm{E}-01$ & $38 \%$ & $1.12 \mathrm{E}-01$ & 178 \\
\hline
\end{tabular}

$\underline{\text { Rheology and Particle Size Results }}$

The as-received and post-wash Tank 7 slurry is very thin rheologically, settles very quickly, and is nearly Newtonian (very small measured yield stress). The Tank 7 slurry could easily be washed everyday as the settling was virtually complete by the next morning after decanting, adding inhibited water, mixing, and sampling the day before.

The particle size data will be added when the analyses are complete. 
Optimal washing strategy

If significant oxalate removal is needed for SB7, the oxalate would be best removed prior to transferring the sludge to Tank 51. In order to remove a significant portion of the oxalate, the sludge must be washed thoroughly and the other soluble species will be very low.

The appropriate oxalate wash endpoint depends on several factors. First, some oxalate can be handled in the DWPF Chemical Processing Cell (CPC). Testing in SB3 was completed with oxalate concentrations as high as $40,000 \mathrm{mg} / \mathrm{kg}$. Also, approximately $10-50 \%$ of the oxalate is destroyed in DWPF processing. If oxalate removal is needed in preparing SB7 sludge, the oxalate may be removed most efficiently in Tank 7 (or Tank 4). The most flexible method for preparation of sludge for SB7 would be to wash out oxalate in Tank 7 and do minimal washing in Tank 51 . This is because the oxalate is the last to be removed in any washing scenario. Several wash scenarios are discussed below:

- If Tank 7 is washed prior to transfer to Tank 51, the removal of oxalate will require extensive washing to lower the oxalate concentration. In this case, the sodium, potassium and anion concentrations will all be very low. If the oxalate is washed thoroughly in Tank 7 , the washed sludge can be combined with other tanks that are high in sodium concentration in Tank 51.

- If Tank 7 is transferred to and washed in Tank 51, the removal of oxalate will require extensive washing to significantly lower the oxalate concentration. If the sodium is approximately $1 \mathrm{M}$ (typical washing endpoint), less than half of the oxalate will be removed.

\subsection{Conclusions}

A 3-L PUREX sludge slurry sample from Tank 7 was characterized and then processed through a series of inhibited water washes to remove oxalate and other soluble ions. Current plans use Tank 7 as one of the feed sources for Sludge Batch 7 (SB7). Tank 7 is high in oxalate due to the oxalic acid cleaning of Tanks 5 and 6 and subsequent transfer to Tank 7.

Ten decant and nine wash cycles were performed over a 47 day period at ambient temperature. Initially, seven decants and seven washes were completed based on preliminary estimates of the number of wash cycles required to remove the oxalate in the sludge. After reviewing the composition data, SRNL recommended the completion of 2 or 3 more decant/wash cycles to ensure all of the sodium oxalate had redissolved. In the first 7 washes, the slurry oxalate concentration was $12,300 \mathrm{mg} / \mathrm{kg}(69.6 \%$ oxalate removal compared to $96.1 \%$ removal of the other soluble ions). After all ten decants were complete, the slurry oxalate concentration was $3,080 \mathrm{mg} / \mathrm{kg}(89.2 \%$ oxalate removal compared to $99.0 \%$ of the other soluble ions. The rate of dissolution of oxalate increased significantly with subsequent washes until all of the sodium oxalate had been redissolved after seven decant/wash cycles. The measured oxalate concentrations agreed very well with Jeff Gillam's predictions for washing of the Tank 7 sample.

Highlights of the analysis and washing of the Tank 7 sample include:

- Sodium oxalate was detected in the as-received filtered solids. $95 \%$ of the oxalate was insoluble (undissolved) in as-received slurry.

- No sodium oxalate was detected in the post-wash filtered solids.

- Sodium oxalate is the last soluble species that redissolves during washing with inhibited water. In order to significantly reduce the sodium oxalate concentration, the sludge must be highly washed, leaving the other soluble anions and cations (including sodium) very low in concentration. 
- The post-wash slurry had $<2 \%$ of the soluble anions and cations remaining, with the exception that for sodium and oxalate

- The yield stress of as-received and post-wash slurry was $<1 \mathrm{~Pa}$.

The settling rate of slurry was very fast allowing the completion of decant/wash cycles each day.

\subsection{Recommendations}

The recommended strategy for developing the oxalate target for sludge preparation includes the following steps:

1. CPC simulant testing to determine the percent oxalate destruction and acid mix needed to produce a predicted redox of approximately $0.2 \mathrm{Fe}^{+2} / \Sigma \mathrm{Fe}$ in a SME product while meeting all DWPF processing constraints.

2. Perform a DWPF melter flammability assessment to ensure that the additional carbon in the oxalate together with other carbon sources will not lead to a flammability issue.

3. Perform a DWPF glass paper assessment to ensure the glass produced will meet all DWPF glass limits due to the sodium concentration in the sludge batch.

The testing would need to be repeated if a significant CPC processing change, such as an alternative reductant to formic acid, is implemented. 


\section{ACKNOWLEDGEMENTS}

The authors would like to acknowledge and thank a number of people who worked together to develop the information that is summarized in this report. The following people made significant contributions:

The sample was handled capably by the SRNL shielded cells operators. The task was led by Mona Galloway but was supported by almost all of the shielded cells technicians, especially Monica Jenkins and Jane Howard. The Tank 7 sample was washed and decanted daily, a Herculean task in the shielded cells which included daily analyses of solids, density, $\mathrm{pH}$ and sample preparation for delivery to AD. Steve Beard and Babb Attaway managed the tasks capably.

A number of researchers and technicians in Analytical Development were instrumental in completing the analyses reported in the document. The majority of the analyses were completed by Jacob Venzie (ICP-AES) and Boyd Wiedenman (IC). In addition, we had support from Curtis Johnson (AA), Kathy White (Carbon, Titration), and David Missimer (XRD). And Leigh Brown capably coordinated the analyses.

Holly Hall capably handled the disposition of residue generated during preparation and as a result of analyzing the samples.

Jeff Gillam predicted the composition of the SB7 batch, including the redissolution of oxalate. His spreadsheet was modified to simulate the actual cells washing and did an excellent job of predicting the redissolution of sodium oxalate during washing of the Tank 7 sample in the cells. 


\subsection{References}

1 Fellinger, T.L., 2009 Tank 7F Sludge Slurry Characterization and Wash Studies, HLWDWPF-2009-0027, Rev 0, Savannah River Site, Aiken, SC 29808 (2009).

2 Lambert, D.P., Tank 7F Sludge Slurry Oxalate Sample Studies, SRNL-RP-2009-00867, Rev 0, Savannah River Site, Aiken, SC 29808 (2009).

3 Fellinger, T.L., Tank 7, e-mail dated 8-6-2009.

4 Fellinger, T.L., Additional Scope for Tank 7, e-mail dated 10-19-2009.

5 Herman, C.C., D.C. Koopman, D.R. Best, M.F. Williams, Sludge Batch 3 Simulant Flowsheet Studies: Phase I SRAT Results, WSRC-TR-2003-00088, Revision 0, Savannah River Site, Aiken, SC 29808 (2003).

6 Herman, C.C., D.C. Koopman, D.R. Best, M.F. Williams, Sludge Batch 3 Simulant Flowsheet Studies: Phase II SRAT/SME Results, WSRC-TR-2003-00158, Revision 0, Savannah River Site, Aiken, SC 29808 (2003).

7 Bannochie, C.J., J. M. Pareizs, D.C. Koopman, Sludge Batch 2/3 Blend SRAT Cycle in the SRNL Shielded Cells, WSRC-TR-2004-00097, Revision 0, Savannah River Site, Aiken, SC 29808 (2004).

8 Coleman, C.J. Aqua Regia Dissolution of Sludge for Elemental Analysis, Manual L16.1, Procedure ADS-2226, Rev. 7, Savannah River Site, Aiken, SC 29808 (2008).

9 Coleman, C.J. Alkali Fusion Dissolutions of Sludge and Glass for Elemental and Anion Analysis, Manual L16.1, ADS-2502, Rev. 6, Savannah River Site, Aiken, SC 29808 (2008).

10 Smith, G.L. Characterization of Analytical Reference Glass - 1 (ARG-1), PNL-8992, Pacific Northwest (National) Laboratory, Richland, WA (1993).

11 Lambert, D.P., Analysis of June 2009 Tank 7 3-L Sample, SRNL-3100-2009-00232, Rev. 0, Savannah River Site, Aiken, SC 29808 (2009).

12 Lambert, D.P., Analysis of June 2009 Tank 7 3-L Sample, SRNL-3100-2009-00232, Rev. 1, Savannah River Site, Aiken, SC 29808 (2009).

13 Gillam, J.M. SB6-16_081309_for SBP.xls, Savannah River Site, Aiken, SC 29808 (2009).

14 Pareizs, J.M., Radioactive Sludge Washing With Gravity Settling, E\&CPT Work Instruction ITS-WI-0017, Savannah River Site, Aiken, SC 29808 (2007)..

15 Pareizs, J.M., Weight Percent Solids Determination Using A Furnace or Oven, Manual L29, Procedure ITS-0078, Rev 0, Savannah River Site, Aiken, SC 29808 (2007).

16 Bannochie, C.J., Shielded Cells Operation Supernate and Slurry Density, Manual L29, Procedure ITS-0118, Rev. 0, Savannah River Site, Aiken, SC 29808 (2007).

17 Darby, R., Chemical Engineering Fluid Mechanics, 2nd edition. Marcel Dekker: 2001.

18 Kilpatrick, L.L., Solubility of Sodium Oxalate and Sodium Tetraphenylborate in DWPF Supernate, DPST-84-341, Savannah River Plant, Aiken, SC 29808 (1984). 


\section{Appendix A - Tank 7 Post-wash Rheology Results}
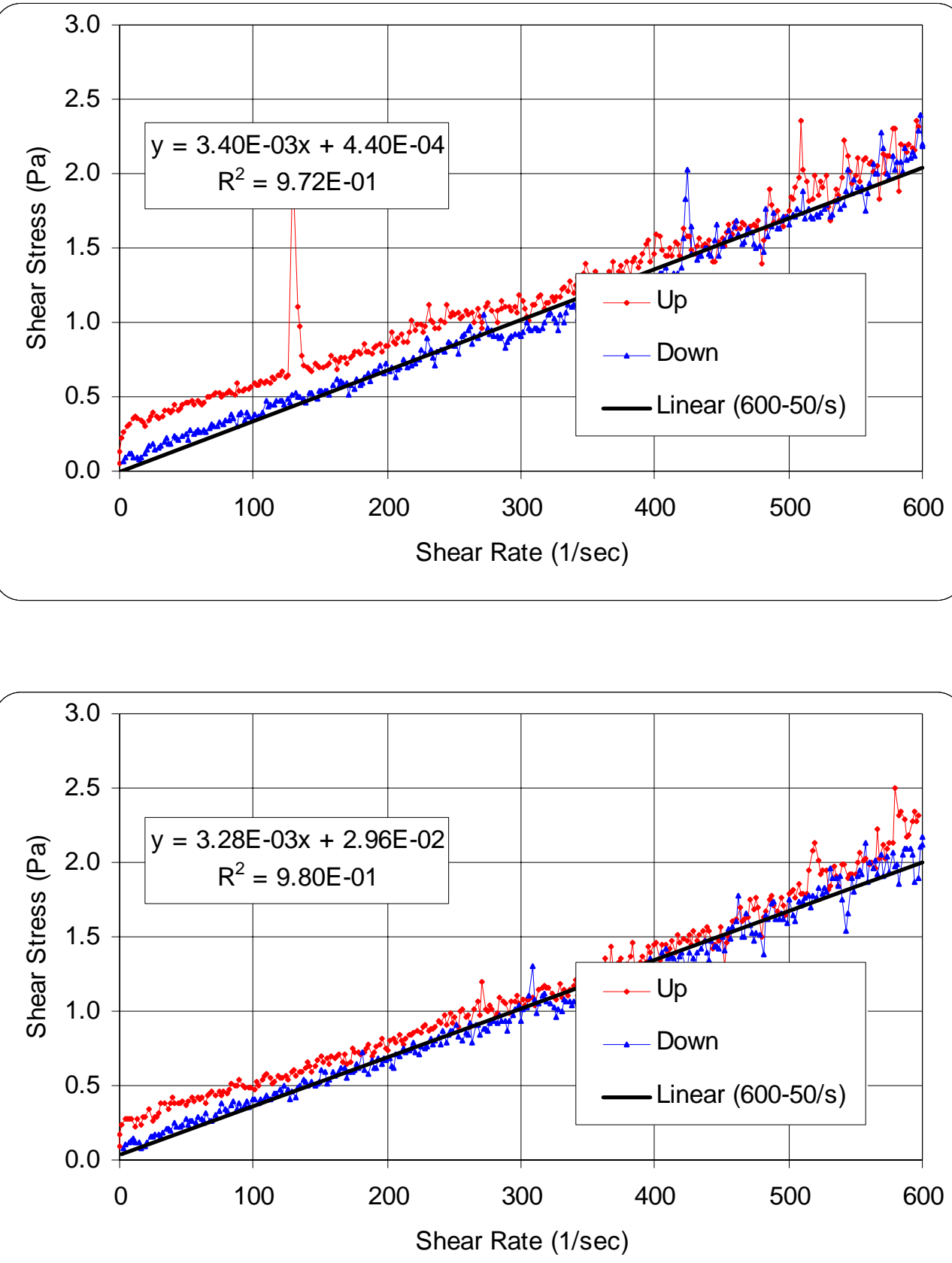


\section{Distribution:}
A. B. Barnes, 999-W
N. E. Bibler, 773-A
D. A. Crowley, 773-43A
C. M. Jantzen, 773-A
S. D. Fink, 773-A
D. K. Peeler, 999-W
B. J. Giddings, 786-5A
M. E. Stone, 999-W
C. C. Herman, 999-W
C. J. Bannochie, 773-42A
S. L. Marra, 773-A
D. C. Koopman, 999-W
F. M. Pennebaker, 773-42A
B. R. Pickenheim, 999-W
H. B. Shah, 766-H
S. H. Reboul, 773-A
J. M. Gillam, 766-H
D. P. Lambert, 773-
B. A. Hamm, 766-H
J. M. Pareizs, 773-A
D. D. Larsen, 766-H
D. R. Click, 773-A
M. T. Keefer, 766-H
J. E. Occhipinti, 704-S
D. C. Sherburne, 704-S
A. I. Fernandez, 999-W
J. F. Iaukea, 704-30S
R. T. McNew, 704-27S
J. P. Vaughan, 773-41A
L. M. Chandler, 773-A
M. J. Barnes, 773-A
J. W. Ray, 704-S
T. L. Fellinger, 704-26S
L. H. Connelly, 773-A
C. M. Gregory, 773-A
L. W. Brown, 773-A

E. W. Holtzscheiter, 704-15S

H. H. Elder, 704-24S

J. M. Bricker, 704-27S 